\title{
UWARUNKOWANIA POWSTAWANIA I FINANSOWANIA FIRM TECHNOLOGICZNYCH
}

Pawet Głodek

Uniwersytet Łódzki

\begin{abstract}
Abstrakt
Funkcjonowanie małych firm technologicznych jest jednym z wyznaczników nowoczesnej gospodarki wykorzystującej nowe rozwiązania techniczne do budowania swojej konkurencyjności na rynkach międzynarodowych. Procesy ich powstawania są wypadkową szeregu czynników, stąd też mamy do czynienia $\mathrm{z}$ różnorodnością ich typów i zachowań biznesowych. Istotne miejsce $\mathrm{w}$ tej grupie przedsiębiorstw zajmują firmy $\mathrm{z}$ obszaru biotechnologii. $\mathrm{Na}$ początku swojego funkcjonowania stykają się one zwykle ze szczególnie dużymi wyzwaniami - dzięki temu stanowią wartościowy przypadek do analiz strategii powstania przedsiębiorstwa.

Niniejszy artykuł podejmuje problematykę analizy uwarunkowań towarzyszących procesom tworzenia małych firmy technologicznych. Szczególny nacisk położony zostanie na dwa obszary. Pierwszy z nich to zagadnienie ryzyka i relacji ryzyka tworzenia firmy z jej charakterystyką. W tym kontekście analizie poddane zostaną czynniki składowe ryzyka, tj. czynnik nowości (wpływający na prawdopodobieństwo wystąpienia niekorzystnych zjawisk) oraz czynniki kształtujące zapotrzebowanie kapitałowe firmy (wpływające na wysokość ewentualnej straty). Drugi obszar to konsekwencje charakterystyki tworzącej się małej firmy technologicznej (w tym ryzyka) na uwarunkowania jej finansowania ze źródeł zewnętrznych. Pomimo że przedstawione rozważania posiadaja głównie charakter teoretyczny, to zawarte są w nich odwołania empiryczne, które dotyczą przedsiębiorstw z branży biotechnologicznej.
\end{abstract}

\section{Uwarunkowania procesu powstania małej firmy technologicznej}

Proces powstawania małej firmy technologicznej charakteryzuje się czynnikami, których łączne wystapienie wyróżnia tę grupę przedsiębiorstw. Zalicza się do nich:

1) wykorzystanie nowej wiedzy w procesie powstawania przedsiębiorstwa, 
2) konieczność sprostania uwarunkowaniom rynkowym odnoszącym się do produktów bazujących na nowych rozwiązania technicznych,

3) unikatowe cechy założycieli firm technologicznych.

Zostaną one omówione poniżej.

\section{Powstanie firmy technologicznej wraz z nowq wiedzq}

Powstanie firmy technologicznej nierozerwalnie wiąże się z wykorzystaniem zaawansowanej technologii. Tworzy ona podstawę, na bazie której firma będzie funkcjonować. Przedsiębiorcy wnoszą do nowo powstającej firmy inicjatywę, energię i wizję. Zaawansowana technologia uzupełnia te cechy o unikatową przewagę konkurencyjną nad istniejącymi firmami lub stanowi bazę do stworzenia zupełnie nowego rynku [Roberts, 1991].

Zastosowanie nowej technologii jest $\mathrm{z}$ definicji podstawową różnicą między małymi firmami technologicznymi a innymi grupami małych przedsiębiorstw. $Z$ procesem jej pozyskania i implementacji związane są główne zagadnienia charakterystyczne dla przedsiębiorstw technologicznych we wczesnych fazach ich rozwoju. W tej sekcji podzielono je na trzy grupy - związane odpowiednio z technologią bazowa, charakterystyką przedsiębiorców oraz rynków.

Przy obecnym wysokim stopniu rozwoju technologicznego rola indywidualnych, niezależnych wynalazców drastycznie zmniejsza się [Stankiewicz, 1994]. Praca nad nowymi technologiami wymaga specjalistycznej wiedzy, sprzętu i doświadczenia. Z tego też powodu podstawowym źródłem technologii bazowych dla małych firm technologicznych są organizacje, w których wcześniej pracowali ich założyciele, a firmy technologiczne to w większości firmy spin-off.

E. B. Roberts [1991] sformułował teoretyczny model transferu technologii $\mathrm{z}$ organizacji źródłowej do nowej firmy technologicznej (rysunek 1). Niewielu założycieli małych firm technologicznych opuszcza poprzednie miejsce zatrudnienia $\mathrm{z}$ już dopracowanym technicznie produktem. Pozyskana technologia ma zwykle charakter wiedzy i umiejętności, które wymagają zaadaptowania do potrzeb nowej firmy (jak również produktu, rynku, procesów produkcyjnych itp.). Zastosowanie tej technologii wiąże się więc ściśle $\mathrm{z}$ podjęciem przez przedsiębiorcę samodzielnych działań $\mathrm{B}+\mathrm{R}$, które są częścią procesu dokonywania innowacji technicznej. Aby wejść na rynek, firma musi doprowadzić ten proces do końca, tak by posiadaną wiedzę technologiczną przekształcić w produkt możliwy do sprzedaży na rynku. Badania przeprowadzone przez R. P. Oakeya [1995] wśród małych firm z sektora zaawansowanej 
technologii wskazują że prawie dziewięćdziesiąt procent z nich prowadziło własne działania badawczo-rozwojowe przed uruchomieniem sprzedaży pierwszego produktu.

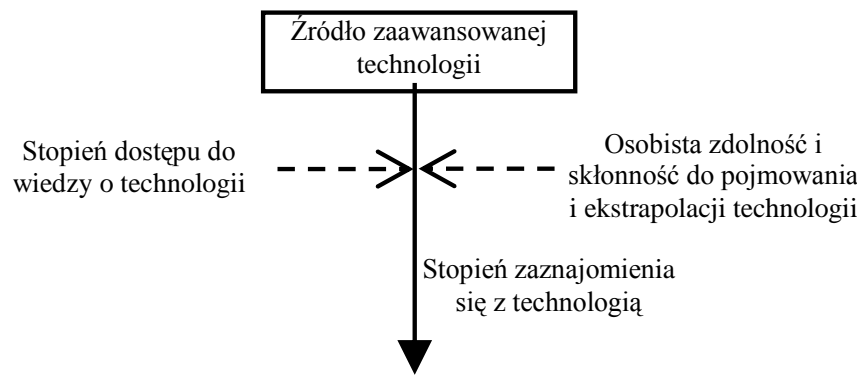

Technologia, która nadaje się

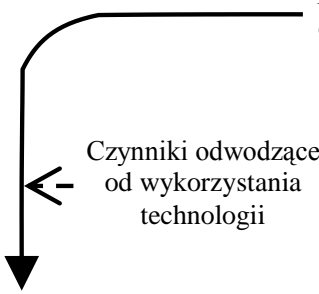

do użytku we własnej firmie

Technologia zapomniana

lub przestarzała

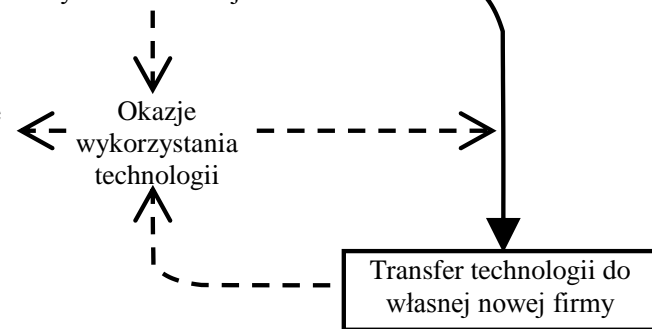

Rysunek 1. Schemat transferu technologii do nowej firmy technologicznej Źródło: Roberts, 1991.

\section{Produkty zaawansowane technologicznie - uwarunkowania rynkowe}

W zakresie marketingu produktów innowacyjnych można zidentyfikować dwa istotne wymiary. Pierwszym z nich jest strona podaży i zmiany w produkcji i dostarczaniu na rynek nowej technologii, związane $\mathrm{z}$ nowymi produktami, drugim - strona popytu i zmiany w nowej technologii konsumpcji i zakupów, związane z nowymi produktami. Każdy $\mathrm{z}$ wymiarów powoduje zmiany w sytuacji marketingowej i co za tym idzie - problemy marketingowe firm. Razem tworzą one kontekst, w ramach którego firmy muszą opracować własną strategię marketingową i który oddziałuje na ich rezultaty [Gardner, Johnson, Lee, Wilkinson, 2000]. Uproszczoną klasyfikację innowacji według tych wymiarów prezentuje rysunek 2 . 


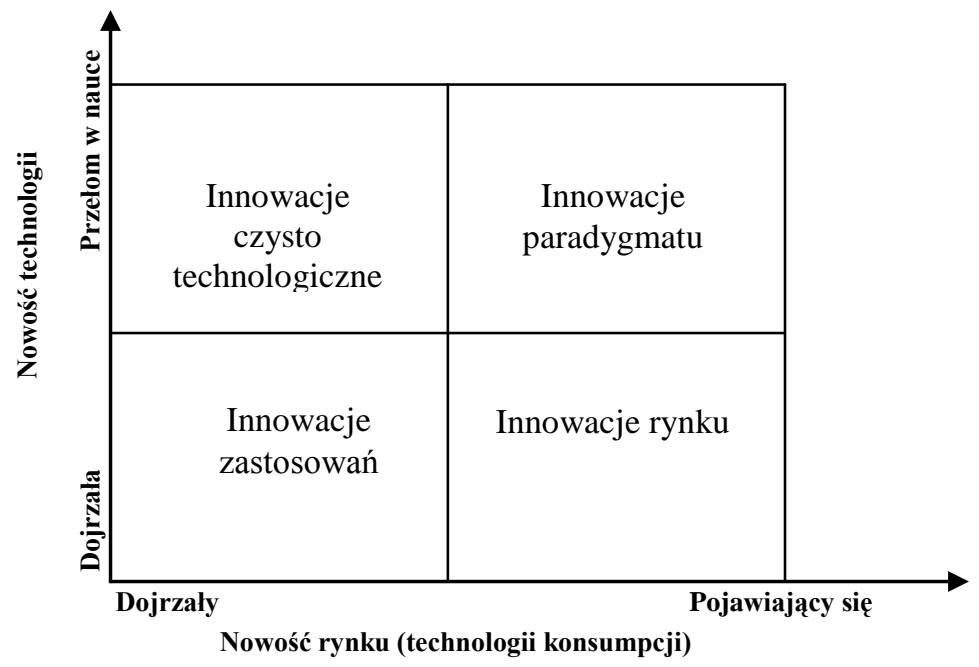

Rysunek 2. Klasyfikacja innowacji według kryterium nowości rynku i technologii

Źródło: opracowanie własne na podstawie Abernathy, Clark, 1985.

W przypadku produktów zaawansowanych technologicznie mamy do czynienia $z$ sytuacją innowacji czysto technologicznych i innowacji paradygmatu. Produkty te $\mathrm{z}$ definicji oparte są na zastosowaniu zaawansowanych technologii, mogą jednakże wykazywać znaczne zróżnicowanie z punktu widzenia nowości ich parametrów rynkowych lub - inaczej mówiąc - z punktu widzenia zakresu zmian technologii konsumpcji lub zakupu tych produktów.

Szczególną sytuacją są innowacje paradygmatu, które wykorzystują zaawansowanie technologiczne i mają zmienione funkcje użytkowe, czyli stanowią nowość w kategoriach rynkowych. Bazując na terminologii M. Portera [1996], rynki tego rodzaju produktów zaklasyfikować można jako sektory pojawiające się. To właśnie pojawienie się na rynku nowych produktów bazujących na nowych rozwiązaniach technologicznych jest główną (choć nie jedyną) przyczyną ich powstawania.

Podstawową cechą sektorów pojawiających się jest brak reguł, które nimi rządzą i co za tym idzie - duża zmienność ich otoczenia [Gardner, Johnson, Lee, Wilkinson, 2000]. Sytuacja taka m.in. drastycznie zmniejsza szanse na w miarę dokładne oszacowanie wielkości sprzedaży i jej stopy wzrostu [Duhamel, Franzetti, Heese, 1995]. Dla nowych podmiotów stanowi to szansę na odniesienie sukcesu, ale jest także poważnym źródłem 
dodatkowego ryzyka. Cechami strukturalnymi sektorów pojawiających się są m.in. [Porter, 1996]:

1) niepewność techniczna - dotyczy ona niepewności co do tego, które z rozwiązań technicznych, modeli konfiguracji produktu czy też technologii tworzących nowy sektor będzie najlepsze, a ponadto które z rozwiązań zostanie zaakceptowane przez rynek jako standard;

2) niepewność strategiczna - ponieważ nie wyróżniono żadnej „właściwej” strategii, firmy próbują różnych sposobów usytuowania marketingu, obsługi wyrobu i rynku, stosując odmienne konfiguracje wyrobu czy technologie produkcji; przyczyną tego jest fakt, że firmy działają przy bardzo ograniczonej informacji o konkurentach, cechach i preferencjach klientów oraz warunkach w sektorze w fazie jego pojawiania się; nikt nie zna wszystkich swoich konkurentów, a wiarygodne dane o wielkości sprzedaży sektora i o udziale w rynku są niedostępne;

3) wysokie koszty początkowe - kombinacja małego wolumenu produkcji oraz nowości wpływa na konieczność ponoszenia przez podmioty funkcjonujące $\mathrm{w}$ ramach sektorów pojawiających się wysokich kosztów początkowych; w tym kontekście najtrudniejszy jest zwykle etap początkowy, gdyż relatywnie szybko pojawiają się rozwiązania prowadzące do doskonalenia metod produkcji, dystrybucji itp.

Działalność w sektorach pojawiających się związana jest $\mathrm{z}$ dodatkowym ryzykiem dotyczącym potencjalnych ograniczeń lub różnego rodzaju utrudnień w rozwoju. Są to m.in.: niemożność uzyskania surowców i komponentów, okres gwałtownego wzrostu cen surowców, brak infrastruktury, brak norm wyrobów lub technologii, postrzegane prawdopodobieństwo przestarzałości, rozterki klientów, nierówna jakość wyrobów, opinia i wiarygodność w środowisku finansowym, zezwolenia władz, wysokie koszty czy reakcja jednostek zagrożonych pojawieniem się nowego sektora.

Niezależnie od innowacyjności rynkowej produktów bazujących na zaawansowanej technologii wiele $\mathrm{z}$ cech wymienionych powyżej powtarza się w charakterystyce rynków dokonanej przez D. M. Gardnera i innych [Gardner, Johnson, Lee, Wilkinson, 2000]. Według nich, w porównaniu do rynków niezaawansowanych technologii, charakteryzują się one m.in. większą zmiennością, mniejszą standaryzacją produktów i zwiększonym ich zróżnicowaniem. $Z$ drugiej strony można spodziewać się ich szybszego rozwoju oraz niższych barier wejścia.

Istotnym instrumentem konkurencyjności na rynkach produktów wysokiej techniki stają się innowacje. W przemyśle elektronicznym, 
instrumentów naukowych czy instrumentów precyzyjnych często mogą być one warunkiem osiągnięcia przez firmę przewagi konkurencyjnej [Geroski, 1994]. Konsekwencją tego faktu są nieustannie pojawiające się nowe rozwiązania techniczne, które w krótkim czasie dezaktualizują istniejące już technologie. Skraca się więc cykl życia produktu, wzrasta stopień niepewności związanej z działaniami konkurencji, a przedsiębiorstwo musi ponosić znaczne koszty związane $\mathrm{z}$ badaniami i rozwojem nowych produktów (technologii). Kapitał intelektualny staje się głównym zasobem podmiotów gospodarczych [Aggarwal, 1999].

R. Aggarwal [1999] wskazuje na szczególne zależności występujące między zaawansowaną techniką i globalizacją. Technologia pozwala na globalizację biznesu, podczas gdy globalizacja czyni technologię bardziej zyskowną. W rezultacie sektory wysokiej techniki często charakteryzują się wysokim stopniem umiędzynarodowienia operacji.

A. Hughes i B. Moore [1998] wskazuja, iż zależność ta jest prawdziwa również $\mathrm{w}$ odniesieniu do małych firm technologicznych. W porównaniu $\mathrm{z}$ małymi firmami operującymi w sektorach konwencjonalnych wykazuja one znacznie większą liczbę konkurentów zagranicznych.

\section{Założyciele małych firm technologicznych}

Wysokie wymagania dotyczące wiedzy technicznej, stanowiącej bazę powstania poszczególnych małych firm technologicznych, w znacznym stopniu determinują charakterystykę ich założycieli. Wyniki badań prowadzonych w wielu krajach europejskich dość jednoznacznie wskazuja na występowanie pewnych cech typowych dla tej grupy przedsiębiorców często określanych mianem przedsiębiorców technicznych. Przedsiębiorcy techniczni w przytłaczającej większości legitymują się wykształceniem wyższym (dość często stopniem doktora), właściwie wszyscy są mężczyznami, posiadają wcześniejsze doświadczenie zawodowe związane $\mathrm{z}$ pracą $\mathrm{w}$ centrach badawczych, firmach przemysłowych i instytucjach naukowo-badawczych. Podsumowując, można stwierdzić, że przedsiębiorcy techniczni stanowią grupę osób dojrzałych, doświadczonych zawodowo i bardzo dobrze wykształconych.

W przypadku przedsiębiorców technicznych wątpliwości budzi badawcza, techniczna bądź też akademicka natura ich doświadczeń zawodowych. Jest ona powodem występującego dość często sceptycyzmu co do ich umiejętności funkcjonowania w biznesie - otoczeniu krańcowo różnym od zasad panujących np. w laboratoriach. Dotyczy to m.in. wiedzy związanej $\mathrm{z}$ zarządzaniem finansami, marketingiem, produkcją, w szczególności kwestionowane są ich umiejętności $\mathrm{z}$ zakresu 
kompleksowego zarządzania wzrostem przedsiębiorstwa [m.in. JonesEvans, 1996]. Moore [1994] sugeruje, że przedsiębiorcy techniczni wykazują skłonność do poświęcania nadmiernej uwagi zagadnieniom czysto technicznym, przez co zaniedbywane są często pozostałe obszary zarządzania przedsiębiorstwem. R. Stankiewicz [1994] prezentuje w tym kontekście dość radykalny pogląd - stwierdza, że w celu odpowiedniej, komercyjnej eksploatacji technologii $\mathrm{w}$ małej firmie technologicznej w wielu przypadkach zarządzanie powinno być na wczesnym etapie rozwoju firmy przekazane osobom $\mathrm{z}$ większym doświadczeniem w biznesie.

Z drugiej strony R. Oakey i S. M. Mukhtar [1998] podkreślaja, że $\mathrm{w}$ procesie tworzenia firmy rola przedsiębiorcy technicznego jest niezastapiona. Chodzi tu głównie o proces dochodzenia do technologii bazowej małej firmy technologicznej. Przedsiębiorca techniczny jest skłonny do sprostania dłuższemu okresowi jej opracowywania niż biznesmen, który nie ma osobistego stosunku do techniki (zwłaszcza że w grę wchodzi finansowanie tego procesu ze środków własnych przedsiębiorcy). Cecha ta jest niezmiernie ważna $\mathrm{w}$ przypadku często przedłużających się i wymagających przezwyciężenia licznych barier technicznych procesów opracowywania produktu. Motorem napędowym do wytrwania przy koncepcji komercjalizacji pomysłu jest często osobiste przeświadczenie o technicznej poprawności i wykonalności przyjętych założeń. I choć sedno sprawy tkwi w zdolności produktu do sukcesu rynkowego, to bez odpowiednio dużej dozy wytrwałości na wcześniejszych etapach produkt może nie dotrwać do fazy komercjalizacji.

\section{Proces zakladania malej firmy technologicznej a czynnik nowości}

Ryzyko w sposób szczególny wiąże się z decyzjami przedsiębiorczymi, $\mathrm{w}$ tym $\mathrm{z}$ decyzjami dotyczącymi założenia firmy oraz jej późniejszego kształtu. Zdolność i skłonność do podejmowania ryzyka są często wskazywane jako główne cechy osobowości przedsiębiorcy. Sposób, w jaki ryzyko jest szacowane, może więc znacząco różnić się pomiędzy poszczególnymi małymi przedsiębiorstwami. Wskazuje się, iż zdecydowana część tych różnic związana jest właśnie z indywidualnym podejściem konkretnego przedsiębiorcy [Smallbone, Leigh, North, 1995], podobnie jak charakter wysoce subiektywny ma postrzeganie okazji rynkowych [Shane, 2004].

Pojęcie ryzyka wiąże się $\mathrm{z}$ postrzeganiem zmienności przyszłych wyników działania oraz ich prawdopodobieństwa zajścia i subiektywnej 
wartości [March, Shapira, 1987]. Ryzyko może być wyrażane ilościowo, przy wykorzystaniu szacunków możliwej straty, która zajdzie w przypadku wystapienia danego zdarzenia, oraz przy szacowaniu prawdopodobieństwa jego wystapienia. T. Mazzarol [2011] wskazuje formułę tak pojmowanego ryzyka jako iloczyn prawdopodobieństwa wystapienia danego zdarzenia oraz wysokości potencjalnej straty/szkody.

W kontekście całościowego ryzyka tworzenia nowej firmy E. Douglas i D. Shepherd [1997] wskazują na występowanie dodatkowego, w porównaniu do firm dojrzałych, czynnika - nowości. Nowość może być związana m.in. z kosztem uczenia się nowych zadań, koniecznością odkrywania nowych ról, konfliktami, jakie niesie z sobą ich wypełnianie i brakiem stabilnych więzi z otoczeniem (zwłaszcza odbiorcami). Tak więc nowość jako czynnik zwiększa prawdopodobieństwo niekorzystnego zdarzenia. Generalnie może być ona rozpatrywana w trzech wymiarach jako:

1) zwiększenie prawdopodobieństwa niekorzystnego zdarzenia wynikające z nowości rynkowej,

2) zwiększenie prawdopodobieństwa niekorzystnego zdarzenia wynikające z nowości technologicznej,

3) zwiększenie prawdopodobieństwa niekorzystnego zdarzenia wynikające z nowości związanej z zarządzaniem. 


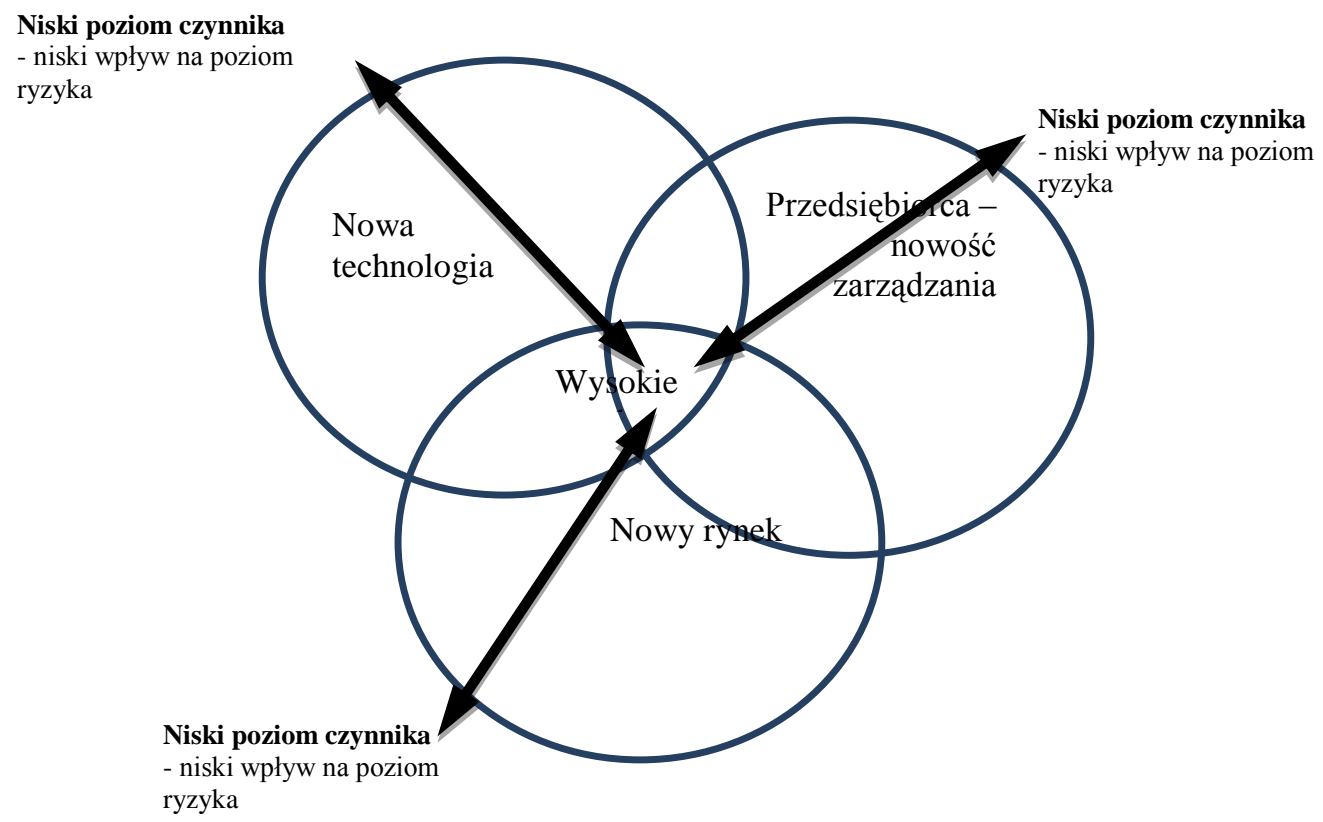

Rysunek 3. Czynniki związane z nowością, odnoszące się do powstającej firmy technologicznej

Poziom całościowego ryzyka wiąże się $\mathrm{w}$ tym ujęciu $\mathrm{z}$ poziomem nowości w ramach każdej z kategorii, czyli również z liczbą kategorii, w których powstająca firma wykazuje cechy nowości (rysunek 3). Do najbardziej ryzykownych projektów należą te, w których występują łącznie wszystkie trzy czynniki.

K. Łobacz [2012] wskazuje na istotne znaczenie procesu przedsiębiorczego uczenia się $\mathrm{w}$ zakresie wykorzystywania zasobów. P. Głodek i K. Łobacz [2013] omawiają proces jego wpływu na obniżanie całościowego poziomu ryzyka dla projektów innowacyjnych.

Powstanie firmy technologicznej związane jest z prowadzeniem działań mających na celu opracowanie i wdrożenie nowej technologii. Łączy się to m.in. z dużymi wydatkami na prace badawczo-rozwojowe, opracowanie $\mathrm{i}$ testowanie prototypu, opracowanie technologii produkcji na skale odpowiadającą danej firmie oraz ze znacznym poziomem ryzyka.

Zasadniczym elementem wpływającym na poziom ryzyka jest odległość technologii od rynku - zakres działań niezbędnych do uruchomienia produkcji. Podejmując decyzję o uruchomieniu nowej firmy, 
założyciel rzadko dysponuje technologią gotową do zastosowania w działalności rynkowej [Oakey, 1995]. Prace nad technologią prowadzone w ramach fazy założycielskiej często zaczynają się na etapie działań B+R. Fakt ten sprawia, iż nie można dokładnie określić czasu trwania fazy założycielskiej, nakładów z nią związanych oraz, co istotne, parametrów ekonomicznych opracowywanej technologii (np. kosztów jednostkowych wytworzenia przyszłego produktu, jakości produktu, wydajności technologii). Im projekt jest bardziej zaawansowany (wykonanie prototypów, partie próbne wyrobów), tym ryzyko techniczne stopniowo zmniejsza się i zmienia profil. $Z$ punktu widzenia ryzyka projektu za kluczowe momenty należy przyjąć: skonstruowanie prototypu, jego przetestowanie oraz dopracowanie technologii produkcji seryjnej.

D. J. Storey i B. S. Tether [1996] podkreślają, iż sektory zaawansowanych technologii często charakteryzują się krótkim przedziałem czasowym istnienia okazji rynkowej (short window of opportunity).

W pewnych przypadkach można zaobserwować swego rodzaju „wyścig po patent". Polega on na tym, że firma, która pierwsza opracuje i opatentuje technologię, wygrywa wszystko, a pozostałe firmy, które nieco wolniej prowadziły badania, nie zyskują nic ${ }^{6}$.

Zastosowanie nowej technologii bądź wprowadzenie na rynek nowego produktu (usługi) wiąże się często $\mathrm{z}$ problemem dostosowania do obowiązujących norm prawnych. Powstaje pytanie, na ile będzie zapewniona zgodność z przepisami w zakresie bezpieczeństwa eksploatacji, ochrony środowiska itp. Szczególnie wysokim wymaganiom prawnym sprostać muszą technologie związane $\mathrm{z}$ medycyną. W odniesieniu do nowych technik i technologii występuje też $\mathrm{z}$ reguły określona skala niepewności dotyczącej możliwości ich ochrony patentowej.

\footnotetext{
${ }^{6} \mathrm{~W}$ tym zakresie część problemów może być ograniczana m.in. poprzez zastosowanie tzw. provisional application, przewidywanej przez prawodawstwo USA.
} 


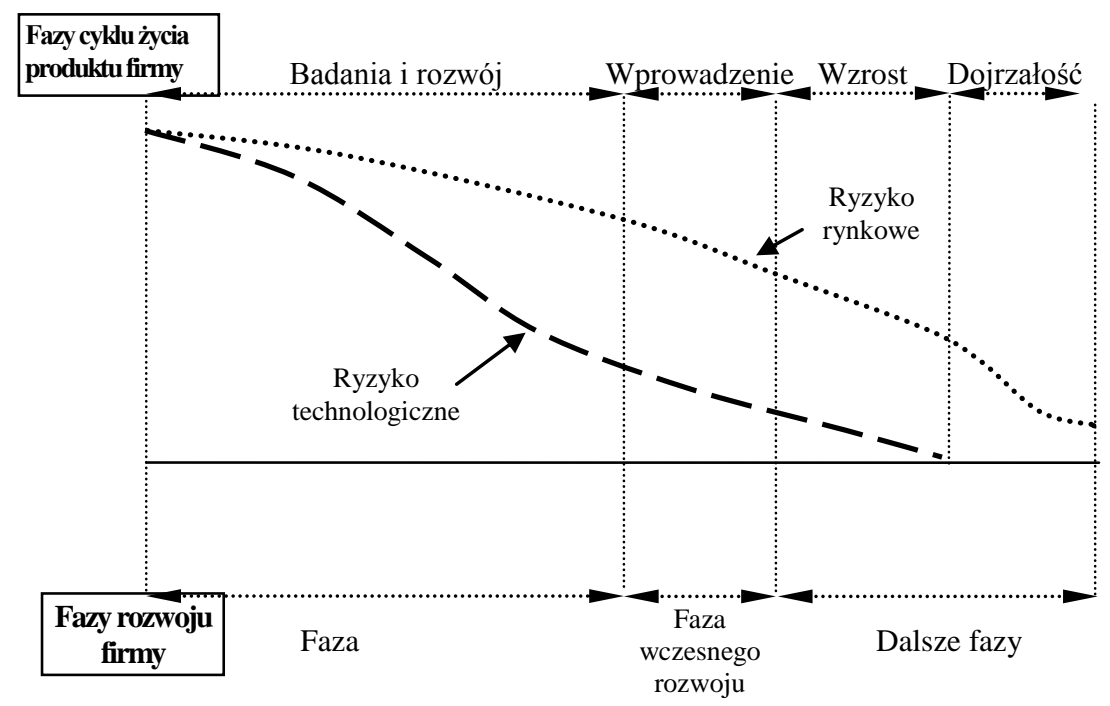

Rysunek 4. Pola ryzyka technicznego i rynkowego w odniesieniu do faz rozwojowych firmy technologicznej

Źródło: opracowanie na podstawie Duhamel, Franzetti, Heese, 1995.

Ryzyko technologiczne nie znika wraz z końcem fazy założycielskiej, gdy rozpoczyna się rynkowe wykorzystanie technologii. Pozostaje ono na pewnym poziomie również $\mathrm{w}$ fazie wczesnego rozwoju i łączy się głównie z czynnikami ekonomicznymi (rysunek 4).

W kontekście powstającej firmy technologicznej nowość rynkowa jest związana z tym, iż reakcja rynku jest tym mniej przewidywalna, im produkt jest bardziej innowacyjny lub inaczej - im jego technologia konsumpcji jest mniej podobna do produktów istniejących na dotychczasowym rynku. Jest ona związana $\mathrm{z}$ tym, czy potencjalni odbiorcy wiedzą, że istnieje produkt, który zaspokaja ich potrzeby, jak go się używa, gdzie go można kupić, jaki jest koszt zakupu i użytkowania.

Kupujący szukają informacji związanych z charakterystyką produktu. Działania reklamowe prowadzone przez sprzedawców mogą być tak samo intensywne, jak poszukiwanie informacji przez potencjalnych nabywców. Nawet na dojrzałych rynkach niezbędne są cykliczne działania reklamowe związane z tym, że wcześniejsza informacja (o sprzedawcy, lokalizacji, jakości, cenie itp.) staje się nieaktualna, a nowi odbiorcy wchodzą na dany rynek z większą lub mniejszą nieświadomością.

Dla zupełnie nowych, rewolucyjnych produktów brakuje zasobów wiedzy zgromadzonej przez konsumentów, a co za tym idzie - nie ma 
przepływu wiedzy (przekazywanej np. ustnie) między konsumentami, która stymuluje potrzebę reklamy. Przezwyciężenie tej bariery wymaga nadzwyczajnych wydatków na reklamę edukującą klientów oraz inne narzędzia promocji. $Z$ punktu widzenia szacowania ryzyka ważne jest względnie duże zróżnicowanie przewidywanych rozmiarów takich wydatków. Dopóki bariera informacji nie zostanie przezwyciężona, osoby zarządzające mogą mieć istotne problemy z oszacowaniem niezbędnych nakładów [Douglas, Shepherd, 1997].

Wprowadzenie nowego produktu na rynek wiąże się z ryzykiem niepowodzenia nowej firmy. Potencjalni odbiorcy są mniej skłonni zaakceptować produkt, gdy nie mają jasnego poglądu na potrzebę jego posiadania, przekonania, że $\mathrm{w}$ wystarczającym stopniu zaspokoi on ich potrzeby lub że nie jest odpowiedniej jakości itp.

Trzeci z aspektów ryzyka nowości - zarządzanie - towarzyszy każdej firmie. Zawsze istnieje niepewność, czy przyjęte założenia planistyczne, zastosowane procedury konstrukcji planu, sposoby jego realizacji itp. były prawidłowe. Niepewność tę w wielu przypadkach można ograniczyć przez wykorzystywanie doświadczenia $\mathrm{z}$ takich samych bądź podobnych projektów. Można założyć, że koszty funkcjonowania przedsiębiorstwa zarządzanego przez osoby mające odpowiednie doświadczenie i wiedzę będą niższe niż w przypadku osób nieposiadających tych cech, a prawdopodobieństwo odniesienia sukcesu będzie większe.

Realizowanie przez powstające przedsiębiorstwo technologiczne projektów innowacyjnych łączy się $\mathrm{z}$ wysokim poziomem ryzyka odnoszącego się do nowości w zarządzaniu, ze względu na występujące w dużym stopniu elementy nowatorstwa i niepowtarzalności. Zaplanowanie przebiegu zjawisk i doprowadzenie do ich realizacji jest znacznie trudniejsze niż dla sytuacji typowych, w odniesieniu do których występuje już określone doświadczenie.

Ryzyko związane $\mathrm{z}$ nowością $\mathrm{w}$ zarządzaniu zależy w dużym stopniu od poziomu wiedzy i doświadczenia założycieli przedsiębiorstwa. Może ono odnosić się do ogólnej wiedzy i doświadczenia, związanych z kierowaniem firmą, personelem, finansami itp. Może również być rozpatrywane w kontekście konkretnego rynku lub produktu. Jeśli są one nowe dla zarządzających firmą, istnieje większe prawdopodobieństwo obrania złej strategii rozwoju, popełniania pomyłek w zarządzaniu marketingiem czy produkcją [Douglas, Shepherd, 1997].

Ryzyko nowości w zarządzaniu jest wyższe w przypadku, gdy zakładaniem nowego przedsiębiorstwa kierują osoby niemające wcześniejszych doświadczeń biznesowych. Taka sytuacja jest często 
spotykana wśród małych firm technologicznych, gdzie założycielami są autorzy rozwiązań technicznych stanowiących podstawę funkcjonowania firmy (opisywani wcześniej przedsiębiorcy techniczni). Ich główną cechą jest szeroka wiedza techniczna oraz podkreślany w wielu opracowaniach niedostatek wiedzy biznesowej i co za tym idzie - brak umiejętności łączenia strategii $\mathrm{w}$ dziedzinie technologii ze strategią przedsiębiorstwa [Berry, Taggart, 1998].

Ryzyko związane $\mathrm{z}$ nowością $\mathrm{w}$ zarządzaniu zmniejsza się wraz ze zdobywaniem doświadczenia i wiedzy związanej tak $\mathrm{z}$ ogólnymi aspektami zarządzania, jak i specyficznej - odnoszącej się do konkretnego produktu, rynku czy przedsiębiorstwa. $Z$ drugiej strony tworząca się i rozwijająca firma potrzebuje rozmaitych umiejętności na poszczególnych etapach rozwoju projektu. Przyjmuje się, iż stopień ryzyka związanego z zarządzaniem, który przybiera największy rozmiar $\mathrm{w}$ fazie założycielskiej, maleje dość powoli i nie zanika.

\section{Czynniki ksztaltujące zapotrzebowanie kapitalowe powstajq̨ej} firmy

Z punktu widzenia zapotrzebowania kapitałowego podstawową cechą fazy założycielskiej jest brak procesów uwalniania kapitału, które w tym przypadku związane są ze sprzedażą produktów wyprodukowanych w nowym obiekcie produkcyjnym i ze zwrotem części zainwestowanego kapitału, który jest zawarty w cenie sprzedanych wyrobów. W fazie tej odbywa się tylko proces wiązania kapitału, tzn. proces zamiany kapitału pieniężnego na kapitał realny. Zapotrzebowanie kapitałowe może być pokryte tylko $\mathrm{z}$ zasobów pochodzących z zewnątrz tworzącego się przedsiębiorstwa.

Główną grupą czynników kształtujących zapotrzebowanie kapitałowe przedsiębiorstwa będącego $\mathrm{w}$ fazie założycielskiej są czynniki związane $\mathrm{z}$ powiększaniem się przedsiębiorstwa. $\mathrm{Na}$ początku tej fazy przedsiębiorstwo nie ma jeszcze żadnego rozmiaru (nie należy do żadnej klasy wielkości). Dopiero realizując inwestycję założycielską poprzez dokonywanie zakupów środków produkcji (majątku trwałego), przedsiębiorca tworzy potencjał produkcyjny przedsiębiorstwa, a tym samym nadaje mu pewną wielkość.

Pierwsze nakłady ponoszone na stworzenie potencjału produkcyjnego pojawiają się już na etapie planowania inwestycji założycielskiej. Często są one związane ze zdobywaniem informacji, dokonywaniem obliczeń i symulacji, badaniami marketingowymi itp. 
Zasadnicze nakłady maja jednak miejsce $\mathrm{w}$ fazie realizacji projektu, która zaczyna się projektowaniem technicznym. W jego ramach występują nakłady związane z zakupem niezbędnych technologii, projektowaniem inwestycji budowlanych, dostosowaniem istniejących obiektów itp. Kulminacja wydatków związana jest $\mathrm{z}$ nabyciem gruntów, budową lub nabyciem nieruchomości, dostosowaniem zakupionych pomieszczeń do potrzeb przedsiębiorstwa, zakupem maszyn i urządzeń produkcyjnych, łącznie $\mathrm{z}$ wyposażeniem pomocniczym, realizacją ewentualnych prac budowlanych itd. W ramach inwestycji założycielskiej, wraz ze zbliżaniem się momentu uruchomienia procesów produkcyjnych, przedsiębiorca zmuszony jest ponieść nakłady związane z rekrutacją i szkoleniem nowych pracowników firmy.

Istotnym elementem, który wpływa na wielkość nakładów związanych $\mathrm{z}$ prowadzonym $\mathrm{w}$ fazie założycielskim procesem inwestycyjnym jest jakość procesu planowania (zarówno w zakresie gospodarki finansowej, jak i planowania samego przedsięwzięcia). Dokładne rozłożenie działań w czasie oraz planowe dążenie do optymalizacji wykorzystania zasobów zmniejsza wielkość potrzebnego do przeprowadzenia inwestycji kapitału. H. E. van Auken i L. Neeley [1998] stwierdzają, że firmy w fazie założycielskiej, w których nieprzykładana jest odpowiednia waga do procesu planowania, wykazują większą skłonność do wykorzystywania kapitału, którego w istocie nie potrzebują lub którego użytkowanie przynosi niską stope zwrotu. $Z$ drugiej strony poprawnie przeprowadzony proces planowania przedsięwzięcia wpływa na skrócenie czasu trwania inwestycji, a co za tym idzie - skrócenie okresu związania kapitału [Behrens, Hawranek, 1991].

W końcowym okresie fazy założycielskiej oprócz procesu inwestycyjnego pojawiają się inne typy wydatków, zwiększające zapotrzebowanie kapitałowe:

1) nakłady związane $z$ wejściem nowej firmy na rynek, obejmujące m.in. zapewnienie odpowiednich kanałów dystrybucji, badania marketingowe czy promocję,

2) nakłady związane $z$ zatrudnieniem pracowników i budową nowej organizacji, obejmujące m.in. płace, premie, ubezpieczenia, szkolenia.

Osobną kategorią jest również zapotrzebowanie związane z koniecznością zapewnienia odpowiedniej wielkości majątku obrotowego, niezbędnego m.in. do zakupu materiałów do procesów produkcyjnych czy środków na płace dla personelu.

Początek fazy wczesnego rozwoju łączy się $\mathrm{z}$ istotną zmianą w funkcjonowaniu młodej firmy. Zaczyna ona operacyjną działalność 
w zakresie swoich procesów podstawowych, sprzedaży wyrobów na rynku i tym samym zaczyna generować własne środki finansowe - są one jednak niewystarczające, by pokryć zapotrzebowanie kapitałowe przedsiębiorstwa. W tej fazie zapotrzebowanie kapitałowe związane jest głównie ze zwiększaniem wykorzystywania mocy wytwórczych - wzrostem produkcji powodującym $\mathrm{w}$ konsekwencji wzrost zapotrzebowania na kapitał obrotowy. Proces ten zwykle wzmocniony jest przez częsty na początku działalności relatywnie długi cykl konwersji gotówki. Nowe na rynku przedsiębiorstwo rzadko ma szansę sprzedawać za gotówkę. Aby zdobyć odbiorców, zmuszone jest oferować im relatywnie długie terminy płatności, co obniża szybkość procesów ekonomicznych w przedsiębiorstwie.

Innym problemem związanym $\mathrm{z}$ okresem wczesnego rozwoju jest ustalenie odpowiedniego poziomu produkcji. E. Garnsey [1996] zwraca uwage, że wiele nowych firm „lawiruje” między niedostatecznym jej poziomem a nadprodukcją. Powodem jest brak stabilności związanej z zachowaniem głównych odbiorców i dostawców oraz brak doświadczenia przedsiębiorcy, który musi te zachowania przewidywać. Proces ten pociąga za sobą zmiany $\mathrm{w}$ układzie procesów podstawowych oraz procesów magazynowania zapasów.

W części przypadków zapotrzebowanie kapitałowe w fazie wczesnego rozwoju łączy się $\mathrm{z}$ dokończeniem procesu inwestycyjnego $\mathrm{z}$ fazy założycielskiej. Dzieje się to zwłaszcza wtedy, gdy priorytetem jest jak najszybsze uruchomienie procesu produkcyjnego, a nieprodukcyjne elementy inwestycji (np. socjalne czy związane $\mathrm{z}$ zarządzaniem) są wykonywane w drugiej kolejności.

$\mathrm{Na}$ ogólną charakterystykę finansową wczesnych faz życia firm technologicznych decydujący wpływ ma fakt, że wiążą się one z pracą nad nową technologią i bazującym na niej produktem, a następnie z wprowadzeniem go na rynek. Mała firma technologiczna $z$ definicji powstaje wraz z nową technologią i nowym produktem na niej bazującym. Charakterystyka zapotrzebowania finansowego wczesnych faz rozwojowych firmy technologicznej ściśle związana jest z charakterystyką finansową wynikającą $\mathrm{z}$ cyklu życia produktu [por. m.in. Duhamel, Franzetti, Heese, 1995; Oakey, Mukhtar, 1998]. Ilustracją takiego podejścia jest rysunek 5, który łączy z sobą finansowe cechy cyklu życia produktu i faz rozwojowych firmy. Na rysunku tym wyróżniono jedynie dwie początkowe fazy rozwojowe firmy, gdyż w dalszych fazach mogą następować znaczne rozbieżności między cyklem życia firmy i produktu, związane $\mathrm{z}$ różnego rodzaju decyzjami strategicznymi, choćby 
z wprowadzaniem następnych produktów ${ }^{7}$. Nieco bardziej szczegółowy podział nakładów omawiany $\mathrm{w}$ dalszej części tekstu przedstawiono na rysunku 6.

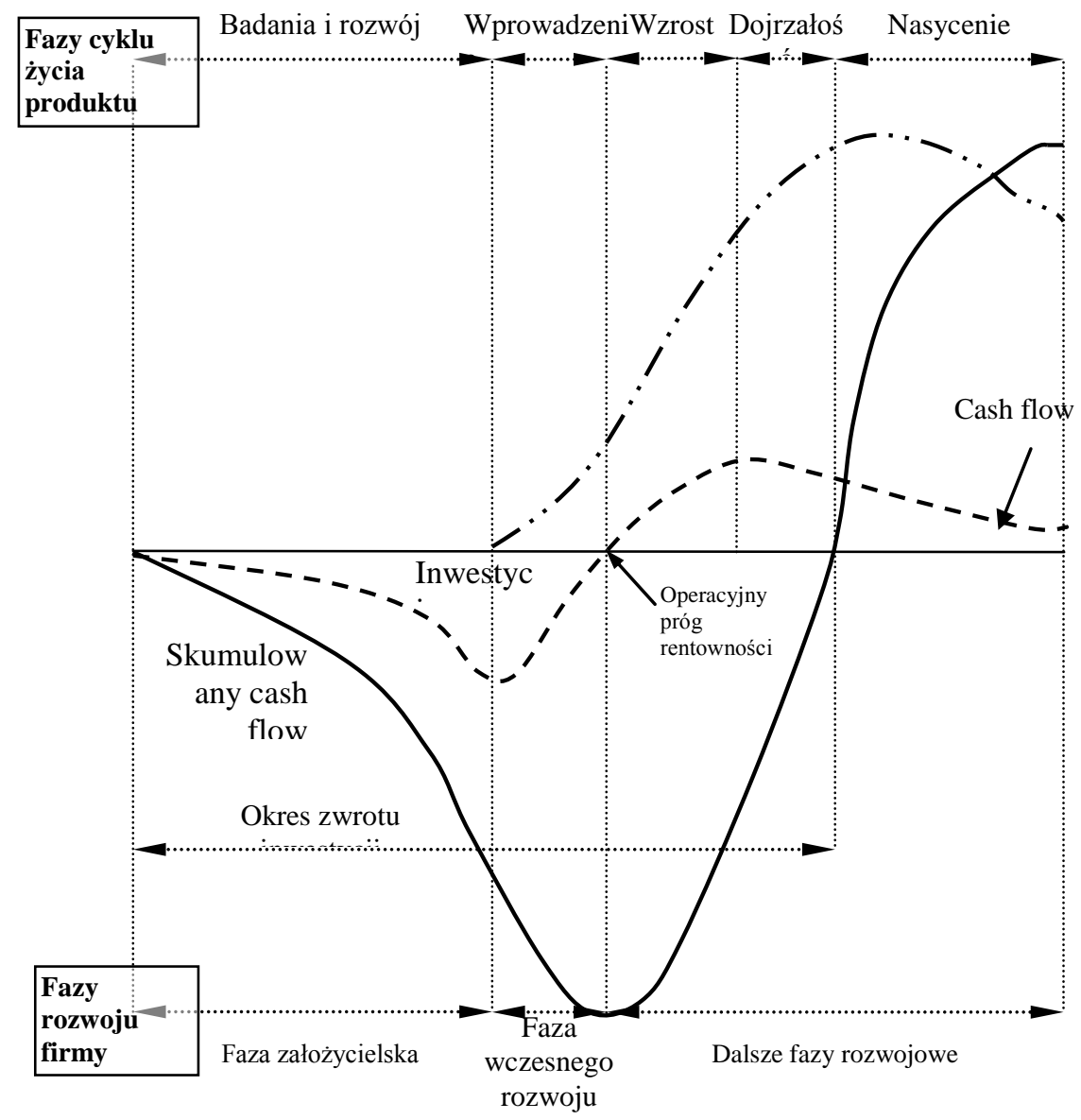

Rysunek 5. Ogólna charakterystyka zapotrzebowania kapitałowego małych firm technologicznych w kontekście cyklu życia produktu Źródło: opracowanie własne na podstawie Duhamel, Franzetti, Heese, 1995.

7 Por. model wydatków na B+R i cykli życia produktów w małych firmach funkcjonujących w sektorach zaawansowanych technologii w: Oakey, Mukhtar, 1998. 


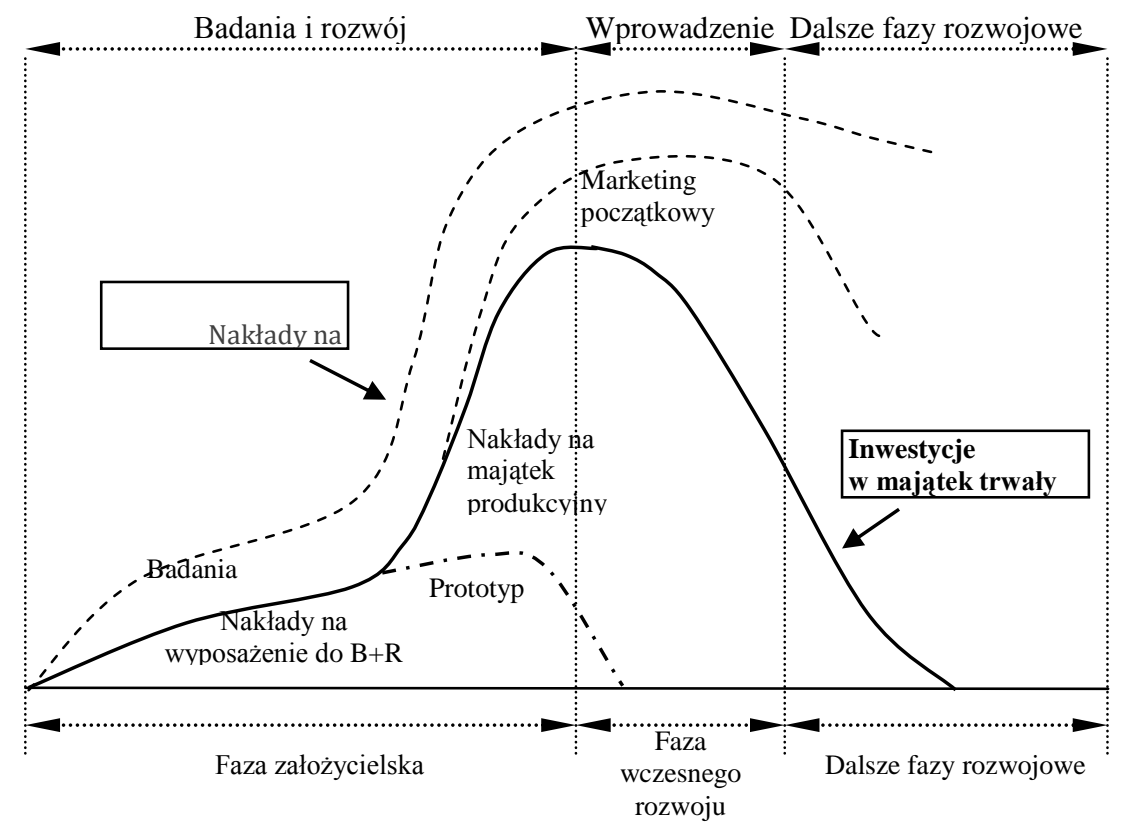

Rysunek 6. Struktura zapotrzebowania kapitałowego we wczesnych fazach życia firmy technologicznej

Źródło: opracowanie własne na podstawie Duhamel, Franzetti, Heese, 1995.

Nakłady na działalność badawczo-rozwojową są specyficznym dla nowych firm technologicznych czynnikiem zwiększającym ich zapotrzebowanie kapitałowe. Jej prowadzenie stanowi podwójne obciążenie dla tworzącej się firmy - wymaga często znacznych nakładów finansowych, a także przedłuża czas trwania fazy założycielskiej i co za tym idzie - czas związania kapitału. $Z$ tego też względu za czynnik, który $\mathrm{w}$ największym stopniu wpływa na wielkość zapotrzebowania kapitałowego związanego z działalnością badawczo-rozwojową uważa się problem „odległości technologii od rynku”. Wiąże się on ze stopniem dopracowania technologii w momencie, w którym przedsiębiorca zaczyna nad nim pracę, czyli inaczej mówiąc jest to ilość pracy, jaka dzieli technologię na danym etapie rozwoju od momentu, w którym w formie gotowego produktu będzie możliwa jej sprzedaż na rynku. Od rozpoczęcia działań badawczo-rozwojowych na własną rękę aż do stworzenia prototypu przedsiębiorca (a potem firma) będzie zaangażowany w kompleksowy, powtarzający się proces złożony $\mathrm{z}$ badań, konsultacji i stopniowego wdrażania poprawek. Im technologia, nad którą rozpoczyna pracę potencjalny założyciel firmy, jest na wcześniejszym etapie rozwoju, tym 
mniejsze szanse na krótki i względnie tani proces badawczo-rozwojowy i na odwrót.

Nakłady na prowadzenia działań badawczo-rozwojowych mogą obejmować wydatki na sprzęt laboratoryjny i wyposażenie potrzebne do prowadzenia badań, nakłady na niezbędne materiały, odczynniki, a także koszty zatrudnienia personelu badawczego. W istocie należy również zwrócić uwagę na to, że pełne zaangażowanie się potencjalnego założyciela $\mathrm{w}$ prace badawcze wiąże się często $\mathrm{z}$ porzuceniem dotychczasowego zatrudnienia, a co z tym związane - $\mathrm{z}$ utratą dochodów przeznaczonych na bieżące utrzymanie przedsiębiorcy (i jego rodziny). Tak więc wydatki osobiste muszą być finansowane $\mathrm{z}$ innych źródeł - najczęściej z oszczędności. Nic więc dziwnego, że potencjalni przedsiębiorcy, wtedy gdy jest to tylko możliwe, starają się godzić obie kwestie i - jak wskazuje E. B. Roberts [1991] - część z nich w początkowym okresie pracy badawczej nad swoim projektem nie angażuje się weń w całości. W niektórych przypadkach zdarza się dodatkowo, że przedsiębiorcy pracujący $w$ instytucjach badawczych lub na wyższych uczelniach, mając zabezpieczone bieżące utrzymanie, wykorzystują sprzęt laboratoryjny i badawczy dostępny w miejscu pracy (przynajmniej przez pewien okres). Niemniej jednak, ten sam autor wskazuje, że rozwój techniczny nowego produktu związany jest często $\mathrm{z}$ długim okresem nieodpowiednio finansowanych badań, prowadzonych w mniej lub bardziej prowizorycznych warunkach, np. w garażu czy w piwnicy przedsiębiorcy.

Długi proces badawczy prócz dużych nakładów rodzi inny poważny problem dla firm technologicznych w fazie założycielskiej - brak produktu możliwego do sprzedaży na rynku. Niemożliwe jest więc rozpoczęcie sprzedaży, dzięki której można generować gotówkę i budować finansowy potencjał przedsiębiorstwa.

Pod koniec fazy założycielskiej pojawia się w firmie technologicznej potrzeba sfinansowania nakładów na charakterystyczne dla niej wydatki jednorazowe, związane z ochroną prawną własności intelektualnej oraz dopuszczeniem produktu do obrotu. Pierwsza kategoria obejmuje ochronę patentową nowej technologii i rozwiązań technicznych stosowanych w nowym produkcie bądź jego procesach produkcyjnych. Druga związana jest z koniecznością uzyskania odpowiednich certyfikatów i zezwoleń umożliwiających sprzedaż nowego produktu. Występowanie i znaczenie wydatków tego typu wiąże się ze specyfiką produktu i regulacjami, które są $\mathrm{z}$ nim związane. Zdecydowanie najpoważniejsze obciążenia $\mathrm{z}$ tego tytułu ponoszą firmy związane $\mathrm{z}$ biotechnologiami stosowanymi $\mathrm{w}$ medycynie. Wprowadzenie na rynek nowego produktu wiąże się w tym przypadku 
z serią testów klinicznych (zgodnie z przepisami dotyczącymi ochrony zdrowia) wymagających $\mathrm{z}$ jednej strony bardzo dużych nakładów finansowych, a $\mathrm{z}$ drugiej powodujących dużą przerwę czasową między opracowaniem produktu a rozpoczęciem jego sprzedaży. Jak stwierdza R. Oakey [1995] w ekstremalnych przypadkach okres ten może rozciagnąć się nawet na 10 lat ${ }^{8}$. W niektórych przedsiębiorstwach branży biotechnologicznej podejmowane są $\mathrm{w}$ tej sytuacji decyzje związane $\mathrm{z}$ rezygnacją $\mathrm{z}$ wprowadzenia na rynek nowego produktu jako leku. Zamiast tego są one wprowadzane jako kosmetyki, suplementy diety itp. W znaczący sposób skraca to czas do wejścia na rynek oraz kilkukrotnie obniża koszty tego procesu'.

W wielu przypadkach innowacje technologiczne są jednocześnie innowacjami rynkowymi. Wymagają one wtedy zwiększonych nakładów związanych z intensywnymi działaniami marketingowymi obejmującymi realizowane $\mathrm{w}$ fazie założycielskiej badania rynkowe oraz - mającą miejsce od wczesnej fazy rozwoju - akcję promocyjną wprowadzająca nowy produkt na rynek.

\section{Hard starts - procesy zalożycielskie malych firm technologicznych $w$ dziedzinie biotechnologii}

Problematyka zróżnicowania powstających małych firm technologicznych jest poruszana przez wielu autorów. Temat ten jest zwykle odnoszony do podziału uruchomień na tzw. soft starts (łatwe starty) i hard starts (trudne starty) Po raz pierwszy został on zastosowany przez Bullocka [1983, w: Storey, Tether, 1996; Moore, 1994], który określa rozpoczynanie działalności przez firmę działająca w sektorach zaawansowanych technologii jako firmę usługową bądź doradczą jako soft start, gdyż wiąże się to $\mathrm{z}$ mniejszym zapotrzebowaniem kapitałowym związanym $\mathrm{z}$ jej uruchomieniem, jak również zapewnia szybsze generowanie gotówki niż w przypadku firmy produkcyjnej potrzebującej znacznej inwestycji kapitałowej i dłużej dochodzącej do pozytywnego cash flow - hard startu.

Porównać można dwa skrajne przypadki: nową firmę biotechnologiczną (jako hard start) i nowe przedsiębiorstwo $\mathrm{z}$ branży maszynowej, działające jako dostawca dla dużej firmy (jako soft start) (tabela 1). Wnioskiem $\mathrm{z}$ tego porównania jest stwierdzenie, że firma biotechnologiczna operuje $\mathrm{w}$ ramach znacznie dłuższego, zawierającego

\footnotetext{
${ }^{8}$ Oczywiście zazwyczaj okres ten jest krótszy i wynosi 3-4 lata.

${ }^{9}$ Strategię taką można wskazać m.in. w przypadku firmy Pharmena - Głodek, Pietras, 2011.
} 
dodatkowe etapy, procesu innowacyjnego, trwającego od początku procesu $\mathrm{B}+\mathrm{R}$ aż do działań marketingowych związanych $\mathrm{z}$ wprowadzeniem produktu na rynek. Jednocześnie, co jest niezmiernie istotne, pokazuje ono również, że firma z branży maszynowej kładzie nacisk na zupełnie inne punkty procesu założycielskiego, tzn. na pozyskanie zaawansowanego wyposażenia produkcyjnego, które w przypadku firmy biotechnologicznej jest znacznie mniej istotne.

Tabela 1. Model zaangażowania firmy na poszczególnych etapach rozwoju produktu niskiej i zaawansowanej technologii

\begin{tabular}{|l|c|c|c|c|}
\cline { 2 - 5 } \multicolumn{1}{c|}{} & B+R & $\begin{array}{c}\text { Opracowanie } \\
\text { prototypu }\end{array}$ & $\begin{array}{c}\text { Innowacja } \\
\text { procesowa }\end{array}$ & Marketing \\
\hline $\begin{array}{l}\text { Nowe przedsiębiorstwo z } \\
\text { branży maszynowej - } \\
\text { poddostawca dla dużej firmy }\end{array}$ & Brak & Brak & Wysokie & Niskie \\
\hline $\begin{array}{l}\text { Nowa firma } \\
\text { biotechnologiczna }\end{array}$ & Wysokie & Wysokie & Niskie & Wysokie \\
\hline
\end{tabular}

Źródło: Oakey., 1995.

R. Oakey [1995] w tym kontekście sformułował cztery uproszczone modele strategii wyboru momentu pełnego zaangażowania się $\mathrm{w}$ działania związane z uruchomieniem nowej firmy technologicznej ${ }^{10}$ :

1) prace badawczo-rozwojowe zostały ukończone przed uruchomieniem firmy; nowa firma jest więc tworzona w momencie, gdy posiada już $\mathrm{w}$ pełni opracowany, gotowy do wypuszczenia na rynek produkt; osiaga bardzo szybko wpływy ze sprzedaży i finansuje z nich dalszy rozwój przedsiębiorstwa; strategia ta jest możliwa, gdy w organizacji źródłowej została opracowana pełna koncepcja technologii i produktu;

2) firma jest utworzona przed pełnym opracowaniem produktu, jednakże proces ten następuje szybko i również szybko osiągnięte zostają

${ }^{10}$ R. Oakey w swojej książce High Technology New Firms: Variable Barriers to Growth zakłada, że zaangażowanie się przedsiębiorcy w ,pełnym wymiarze” w badania nad nowym produktem związane jest $\mathrm{z}$ momentem formalnego uruchomienia nowego przedsiębiorstwa. Decyzję tę należy zapewne łączyć ze stosowaną przez niego metodologią badawczą - badaniami ilościowymi. Oakey sam podkreśla, że w przypadku badań ankietowych takie podejście jest najpraktyczniejsze - łatwo można określić wiek firmy, a z jego pomocą długość poszczególnych działań. W wersji prezentowanej powyżej podejście to zostało nieco zmodyfikowane. 
znaczące wpływy ze sprzedaży (po około roku); są one wystarczające do finansowania wzrostu;

3) początek prac badawczych przedsiębiorcy następuje znacznie wcześniej niż zakończenie opracowania produktu; czas pracy nad nim uwzględniony jest w biznesplanie i trwa od 3 do 5 lat, po czym firma ma szansę osiągnąć pierwsze zyski; zdobywa równowagę finansową w średnim okresie; strategia ta jest typowa dla firm powstających na bazie wyników badań podstawowych, a więc takich, które potrzebują znaczących wysiłków badawczych, by mogły zostać skomercjalizowane w formie produktu;

4) firma jest formalnie utworzona, jak w poprzednim przypadku, przed zakończeniem opracowania produktu, lecz okres pracy nad nim zaplanowany w biznesplanie nie zostaje dochowany i prace rozwojowe są kontynuowane również w dalszym okresie; konieczne są nowe inwestycje i dofinansowanie firmy zewnętrznym kapitałem własnym.

Według R. Oakeya zapotrzebowanie kapitałowe związane $\mathrm{z}$ działaniami $\mathrm{B}+\mathrm{R}$ może więc zmieniać się od relatywnie niskiego, jak w przypadku pierwszym, do bardzo poważnego, niemożliwego do samodzielnego zaspokojenia, jak w przypadku czwartym. Do kategorii czwartej szczególnie często zalicza się firmy z branży biotechnologicznej, gdzie uniknięcie kosztowych badań jest bardzo trudne.

Czynnik znaczącego zapotrzebowania kapitałowego powoduje, że firmy często zmuszone są do rozpoczynania działalności na bazie działalności usługowej po to, by zgromadzić odpowiednie środki na prowadzenie działalności badawczo-rozwojowej, a dopiero później przechodzą na działalność produkcyjną [Storey, Tether, 1996].

Tendencję taką potwierdzają badania E. B. Robertsa [1991], który stwierdził, że w przypadku badanych przez niego firm będących spinoffami z Massachusetts Institute of Technology połowa firm, które zaczęły działalność jako firmy doradcze wprowadziła działalność produkcyjną, przy czym $20 \%$ porzuciło całkowicie działalność doradczą. Jeszcze wyraźniejsza tendencja zaznaczyła się w grupie przedsiębiorstw, które powstały jako firmy realizujące zlecenia badawcze (contracting $B+R)-$ aż $2 / 3 \mathrm{z}$ nich wdrożyło różne formy produkcji. $Z$ drugiej strony żadna $\mathrm{z}$ firm, która rozpoczęła działalność jako produkcyjna, nie porzuciła jej.

Obecnie wiele z przedsięwzięć usługowych i doradczych w sektorach zaawansowanych technologii określa się mianem biznesów pomostowych (bridge businesses). Różnią się one od sytuacji, gdy przedsiębiorca uruchamia nowe przedsiębiorstwo, by „znaleźć się w biznesie” i wtedy 
wyszukiwać kolejne okazje do rozwoju firmy. W przypadku biznesów pomostowych podstawowym celem jest wygenerowanie kapitału niezbędnego do sfinansowania ukończenia pracy nad nową technologią i do uruchomienia produkcji nowego produktu, który będzie $\mathrm{w}$ przyszłości stanowił podstawę egzystencji firmy [Spann, Adams, 1997; Deakins, Graham, Logan, Sullivan, 1997]. Rolę biznesów pomostowych można więc określić jako jedną z przedsiębiorczych metod finansowania działalności przez (w tym przypadku) przedsiębiorców technicznych. Ich znaczenie finansowe przedstawiono na rysunku 7 .

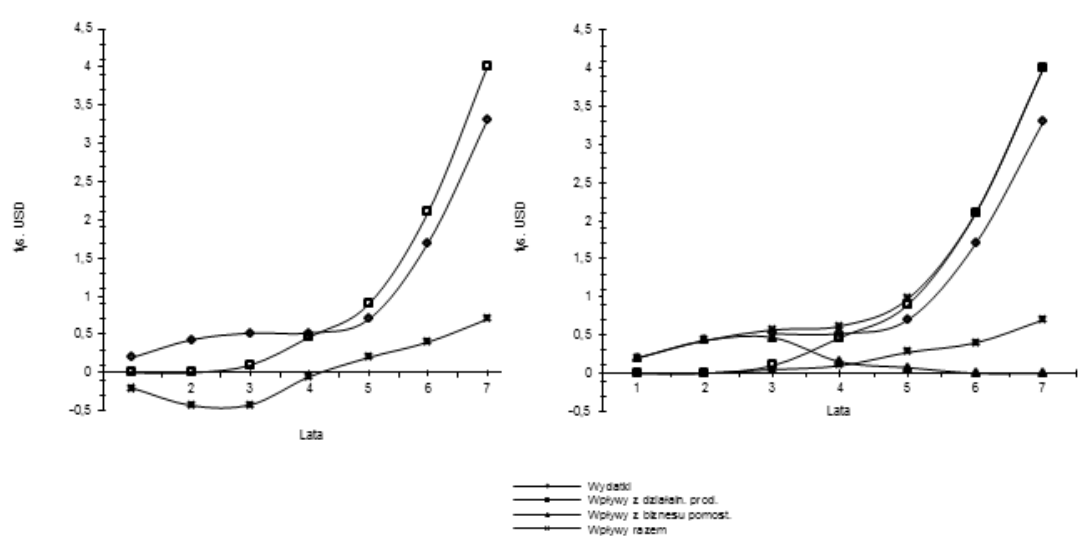

Rysunek 7. Wpływ biznesu pomostowego na zmniejszenie zapotrzebowania kapitałowego nowej firmy technologicznej

Źródło: Spann, Adams, 1997.

Wykres z lewej strony pokazuje sytuację finansową firmy, gdy rozwój produktu następuje bez biznesu pomostowego i przez dłuższy okres (tu 4 lata) firma odnotowuje ujemny cash flow. Wykres z prawej ilustruje sytuację, gdy równolegle $\mathrm{z}$ prowadzonymi pracami badawczymi i wdrożeniowymi prowadzony jest biznes pomostowy, który w pierwszym, najcięższym okresie wyrównuje wydatki związane z pracami $\mathrm{B}+\mathrm{R}$ i wraz $\mathrm{z}$ rozpoczęciem produkcji głównego produktu jest stopniowo porzucany.

Poza nakładami na prace $B+R$ specyfika powstawania firmy technologicznej wpływa na charakterystykę innych kategorii nakładów, $\mathrm{w}$ tym na inwestycje w majątek trwały, a w szczególności związane z nabyciem maszyn i urządzeń niezbędnych do uruchomienia działalności operacyjnej przedsiębiorstwa. Stosowanie zaawansowanych technologii 
wymaga przeważnie maszyn i urządzeń o dużym stopniu specjalizacji i wysokich parametrach jakościowych. Sprzęt ten jest często możliwy do zastosowania tylko $\mathrm{w}$ ramach jednego specjalistycznego procesu technologicznego (lub w ich bardzo ograniczonej liczbie). Zakup i instalacja takiego wyposażenia wymaga zwykle zdecydowanie większych nakładów niż $\mathrm{w}$ przypadku zakupu wyposażenia stosowanego $\mathrm{w}$ firmach bazujących na technologiach tradycyjnych. Ponadto konieczność zastosowania takiego sprzętu zmniejsza znacznie możliwości ograniczenia nakładów na ich pozyskanie (nie można wypożyczyć go od innej firm lub odkupić sprzęt używany). Często występują problemy $\mathrm{z}$ wzięciem go w leasing lub zaciagnnięciem kredytu na jego zakup [Moore, 1994]. Dzieje się tak ze względu na niską płynność specjalistycznego sprzętu występującego np. jako zabezpieczenie kredytu.

\section{Finansowanie powstającej firmy technologicznej - źródła o charakterze rynkowym}

Literatura nie oferuje empirycznego porównania wielkości nakładów początkowych firm technologicznych i firm korzystających z technologii tradycyjnych. Bazując jednak na materiale zgromadzonym w części pierwszej analizy, można wysunąć trzy podstawowe wnioski:

1) w przypadku firm technologicznych pojawia się nowa, poważna kategoria wydatków - działania badawczo-rozwojowe,

2) okres od pierwszych wydatków związanych z fazą założycielską firmy technologicznej do uzyskania bieżącej równowagi finansowej (osiągnięcie operacyjnego progu rentowności) zwykle wymaga dłuższego czasu niż w firmach tradycyjnych,

3) specyfika firm technologicznych ogranicza możliwości stosowania rozmaitych strategii redukcji zapotrzebowania kapitałowego.

\section{Zagadnienie luki na rynku finansowym ${ }^{11}$}

Prawidłowy mechanizm rynkowych powiązań pieniężnych powinien gwarantować pełną zbieżność celów i interesów kapitałodawcy oraz kapitałobiorcy, zapewniając równocześnie elastyczny przepływ kapitału.

Podmioty, które funkcjonują na rynku finansowym, reprezentują własne cele, interesy, systemy wartości i motywacje. Poszczególni uczestnicy rynku mogą inaczej postrzegać konkretne sytuacje rynkowe i związane z nimi szanse i zagrożenia. Może to prowadzić do konfliktu interesów (por. tabela 2) pomiędzy uczestnikami rynku, tj. kapitałodawcami

${ }^{11} \mathrm{~W}$ literaturze angielskojęzycznej używane jest określenie finance gap. 
i kapitałobiorcami, z możliwością dominacji jednej ze stron lub utrzymania wysokiego poziomu konkurencji i równych szans każdej strony.

Tabela 2. Potencjalne płaszczyzny konfliktu interesów kapitałodawcy i kapitałobiorcy na rynku finansowym

\begin{tabular}{|l|l|}
\hline \multicolumn{1}{|c|}{ Interesy kapitałobiorcy } & \multicolumn{1}{c|}{ Interesy kapitałodawcy } \\
\hline $\begin{array}{l}\text { Zakres informacji ujawnianych do } \\
\text { publicznej oceny }\end{array}$ & $\begin{array}{l}\text { Zakres informacji wymaganych do oceny } \\
\text { efektywności decyzji inwestycyjnych }\end{array}$ \\
\hline $\begin{array}{l}\text { Zakres dopuszczalnego } \\
\text { zabezpieczenia z punktu widzenia } \\
\text { kosztów zabezpieczenia i } \\
\text { ograniczenia niezależności } \\
\text { ekonomicznej }\end{array}$ & $\begin{array}{l}\text { Zakres wymaganych zabezpieczeń z punktu } \\
\text { widzenia dopuszczalnego ryzyka transakcji }\end{array}$ \\
\hline $\begin{array}{l}\text { Maksymalny akceptowany koszt } \\
\text { kapitału z punktu widzenia } \\
\text { zabezpieczenia efektywności } \\
\text { podejmowanych przedsięwzięć } \\
\text { i oczekiwań inflacyjnych }\end{array}$ & $\begin{array}{l}\text { Minimalna oczekiwana stopa zwrotu transakcji } \\
\text { z uwzględnieniem spodziewanego poziomu } \\
\text { inflacji i minimalnego akceptowanego ryzyka } \\
\text { konkretnego przedsięwzięcia }\end{array}$ \\
\hline $\begin{array}{l}\text { Wymagany okres zaangażowania } \\
\text { kapitału }\end{array}$ & $\begin{array}{l}\text { Przyjęty okres inwestowania z uwzględnieniem } \\
\text { stopnia preferencji płynności aktywów }\end{array}$ \\
\hline $\begin{array}{l}\text { Organizacja realizacji zobowiązań } \\
\text { wobec kapitałodawcy (z punktu } \\
\text { widzenia płynności finansowej } \\
\text { i zmiennej wartości pieniądza } \\
\text { w czasie) }\end{array}$ & $\begin{array}{l}\text { Oczekiwany wpływ kapitału (z punktu widzenia } \\
\text { płynności finansowej i zmiennej wartości } \\
\text { pieniądza w czasie) }\end{array}$ \\
\hline $\begin{array}{l}\text { Dostosowanie wysokości } \\
\text { pozyskiwanego kapitału do wielkości } \\
\text { oczekiwanej, zgodnie z indywidualną } \\
\text { oceną potrzeb kapitałowych }\end{array}$ & $\begin{array}{l}\text { Angażowanie kapitału w wysokości } \\
\text { dostosowanej do indywidualnej oceny sytuacji } \\
\text { ekonomicznej kapitałobiorcy, jego perspektyw } \\
\text { rozwojowych oraz analizy rynku finansowego }\end{array}$ \\
\hline $\begin{array}{l}\text { Dążenie do zachowania niezależności } \\
\text { ekonomicznej }\end{array}$ & $\begin{array}{l}\text { Zapewnienie możliwości współdecydowania } \\
\text { o działalności kapitałodawcy }\end{array}$ \\
\hline Zrodo: Euak,
\end{tabular}

Źródło: Łukasik, 1998.

Efektem sytuacji, w których zachodzi sprzeczność interesów na rynku finansowym, może być wystąpienie tzw. luki finansowej. Jest ona definiowana jako brak skłonności części dostawców kapitału do dostarczenia środków finansowych na warunkach możliwych do zaakceptowania przez niektóre kategorie (grupy) odbiorców kapitału [Storey, 1994]. 
Zagadnienie istnienia luki finansowej na rynku jest obiektem analizy już od lat trzydziestych ubiegłego wieku. Jednym z pierwszych badań podnoszących to zagadnienie był powstały $\mathrm{w}$ roku 1931 tzw. raport McMillana [Storey, 1994], który stwierdzał na rynku brytyjskim głęboki deficyt długoterminowego kapitału $\mathrm{w}$ wysokości poniżej $200000 £^{12}$. Problem ten, związany z trudnościami pozyskania relatywnie małych kwot kapitału, poruszany był również w wielu innych badaniach i raportach.

Istnienie luki finansowej łączone jest $\mathrm{z}$ istotnymi trudnościami w pozyskiwaniu kapitału zewnętrznego, jakie sygnalizowane są przez małe przedsiębiorstwa czy przedsiębiorstwa nowo powstające. Szczególnie poważnym ograniczeniem jest bariera finansowa dla powstających firm technologicznych. Problem ten przewija się w wynikach badań niezależnie od kraju i czasu, w którym są przeprowadzane. Podobnego zdania są również D. J. Storey i B. S. Tether [1996], którzy - uznając prymat bariery finansowej - stwierdzają: „badania nieprzerwanie potwierdzaja, że przedsiębiorcy postrzegają, że rozwój ich firm w głównej mierze jest w nieracjonalny sposób ograniczany przez brak dostępu do zewnętrznego finansowania".

\section{Finansowanie firmy technologicznej kapitałem obcym}

W kontekście pozyskiwania finansowania zewnętrznego podstawowym zagadnieniem podkreślanym przez literaturę przedmiotu jest brak zgodności charakterystyki tworzącej się firmy technologicznej z wymaganiami instytucji kredytujących działalność przedsiębiorstw.

Dla banku, który jest głównym dostarczycielem kapitału obcego w gospodarce, podstawowym zagadnieniem przy udzielaniu kredytu jest bezpieczeństwo jego spłaty. W sytuacji idealnej kredyt nie powinien nieść z sobą żadnego ryzyka dla pożyczkodawcy. W rzeczywistości każdy kredyt obciążony jest pewnym ryzykiem (ryzykiem kredytowym). Kredytodawcy dążą jednak do jego minimalizacji. $Z$ drugiej strony dominującą cechą firm technologicznych we wczesnych fazach rozwojowych jest wysokie ryzyko ich działalności i co za tym idzie - ich finansowania.

Jednym $\mathrm{z}$ podstawowych aspektów związanych $\mathrm{z}$ małą tolerancją ryzyka przez kredytodawców jest zagadnienie nierównomiernego rozłożenia premii za podwyższone ryzyko projektu. Punktem wyjścia do opisu tego problemu jest stwierdzenie, iż bank osiaga korzyści tylko w przypadku finansowania przedsięwzięć gospodarczych, w których kredytobiorcy są w stanie spłacić kredyt w całości wraz z odsetkami, przy czym można stwierdzić, iż wielkość dochodu banku może być traktowana

\footnotetext{
${ }^{12}$ Przez długi czas kwotę tę nazywano luką MacMillana (ang. MacMillan gap).
} 
jako stała, jeśli tylko finansowany projekt osiagnął pewien minimalny poziom efektywności. W przypadku finansowania projektu ryzykownego, ale związanego z potencjalnym ponadprzeciętnym zyskiem, kredytodawca nie zyskuje niczego. Możliwość uzyskania dodatkowej premii za ryzyko w wyniku realizacji zysków lub wzrostu wartości firmy istnieje jedynie po stronie kredytobiorcy. Powstaje więc sytuacja, w której bank ponosi podwyższone ryzyko finansowania za darmo [Keasey, Watson, 1993]. $\mathrm{Z}$ tych powodów, jak również uwzględniając zmieniające się otoczenie rynkowe, bardziej racjonalne $\mathrm{z}$ punktu widzenia banku jest kredytowanie przedsięwzięć o relatywnie niskim ryzyku inwestycyjnym.

Jednym z kluczowych zagadnień związanych $\mathrm{z}$ opisywanym wyżej problemem jest fakt, że - jak dowodzą J. Stiglitz i A. Weiss [1981] - na rynku kredytu bankowego zostały zaburzone normalne procesy rynkowe związane z regulacją popytu i podaży za pośrednictwem ceny (czyli w tym przypadku wysokości stopy procentowej). Dowodzą oni, iż przyczyną tej sytuacji jest wpływ panującej na rynku asymetrii informacyjnej. Funkcję regulatora podaży na tym rynku przejęły działania banków zmierzające do wyselekcjonowania wiarygodnych kredytobiorców. Jedną z konsekwencji takiego modelu regulacji rynku jest to, że niektórzy $\mathrm{z}$ potencjalnych kredytobiorców mogą być wyłączeni $\mathrm{z}$ dostępu do tego źródła finansowania, nawet jeśli będą przygotowani na zapłacenie ceny wyższej niż aktualnie obowiązująca na rynku.

Problem asymetrycznego rozłożenie informacji został po raz pierwszy zaprezentowany przez Williamsona [1975]. Stwierdził on, iż właściciel firmy posiada lepszą informację o swoim przedsiębiorstwie niż osoba oceniająca firmę z zewnątrz - ma więc większe szanse na poprawną ocenę stanu firmy oraz jej perspektyw. Potencjalnie może wykorzystać ją m.in. podczas ubiegania się o finansowanie projektów swojej firmy przez inwestora dysponującego znacznie gorszą informacją [Binks, Ennew, 1996; Binks, Vale, 1990].

M. R. Binks i C. T. Ennew [1996] zakreślili dwa główne problemy związane $\mathrm{z}$ asymetrią informacyjną. Po pierwsze, banki (lub inni inwestorzy) mogą nie być w stanie uzyskać w pełni wiarygodnej informacji o firmie, która pozwoli trafnie oszacować ryzyko związane z projektem (mającym być finansowanym z kredytu), jego potencjalnej zyskowności oraz kompetencjach właściciela firmy. Po drugie, asymetria informacyjna powoduje ryzyko, iż firmy nie będą postępować w sposób zgodny z umową kredytową (problem monitorowania działalności firm).

W przypadku powstających firm technologicznych pozyskanie wiarygodnej informacji do oceny projektu jest szczególnie trudne 
i kosztowne, łączą one bowiem cechy nowo utworzonych firm i projektów innowacyjnych opartych na technologii. Z punktu widzenia szacowania ryzyka zasadniczy problem stanowi to, że [m.in. Moore, Garnsey, 1992]:

1) sukces jest powiązany $z$ bardzo trudnym do oceny pomysłem bazującym na wiedzy naukowej,

2) firmy bazują na produkcie, który nie jest przetestowany na rynku, nie ma historii, którą można ocenić i którego rynkowy cykl życia może być bardzo krótki.

Z drugiej strony firmy technologiczne posiadają również wszystkie inne cechy typowe dla nowo utworzonych przedsiębiorstw, limitujące możliwość pozyskania wiarygodnej informacji o nich. Firma nie posiada historii kredytowej, dokumentacji finansowej ani nawet rachunku rozliczeniowego, na którego podstawie można oszacować jej średnie obroty. Potencjalny kredytodawca w większości przypadków może liczyć jedynie na informacje, których udziela sam właściciel. Co więcej, nie ma możliwości sprawdzenia kwalifikacji przedsiębiorcy w zakresie zarządzania przedsiębiorstwem i zdolności biznesowych. System produkcyjny nie został jeszcze uruchomiony, więc nie ma danych na temat jego awaryjności czy np. jakości produktu końcowego. Dla potencjalnego kredytodawcy jest to sytuacja, w której dokonanie dokładnego oszacowania poziomu ryzyka wymagałoby indywidualnego i bardzo kosztownego podejścia.

Prócz działań związanych $\mathrm{z}$ wyselekcjonowaniem projektów „bezpiecznych”, kredytodawcy dążą do dalszego zmniejszania ryzyka poprzez stosowanie zabezpieczeń. Stanowią one dla kapitałodawcy gwarancję, iż nawet $\mathrm{w}$ razie niepowodzenia projektu uważanego za bezpieczny, zainwestowany kapitał zostanie przez niego odzyskany. Binks i Ennew [1996] oraz Binks [1996] stwierdzaja, iż do oceny wniosku kredytowego może być zastosowane jedno z dwóch krańcowych podejść podejście dynamiczne (Income Gearing lub Prospect Based Approach) lub podejście statyczne (Capital Gearing Approach), albo też można zastosować podejście pośrednie. Pierwsze z nich polega na ocenie tego, czy strumień dochodów, który byłby generowany przez projekt jest wystarczający do spłaty kredytu i odsetek. Drugie z podejść zwraca uwagę głównie na wartość zabezpieczeń, jakie zostały przedstawione przy wniosku kredytowym. Cechą charakterystyczną podejścia dynamicznego jest to, iż wymaga ono pewnej i dokładnej informacji przy ocenie projektu i kondycji firmy, a także przy monitorowaniu firmy. Koszty takich informacji w przypadku małych firm są poważne, dlatego by ich uniknąć, banki często skłaniają się ku drugiemu z podejść. 
Wymagania stawiane przez bank, dotyczące wartości i jakości zabezpieczeń kredytu (zwłaszcza, choć nie tylko, inwestycyjnego), mogą stanowić bardzo skuteczną barierę dostępu do rynku finansowego. Pełnią one funkcję selekcyjną, gdyż bank nie udzieli kredytu przedsiębiorstwu, które nie posiada majątku wystarczającego do jego zabezpieczenia. Gwarancje nie są wystarczające wówczas, gdy majątek netto przedsiębiorstwa jest mały w porównaniu z wielkością zaciąganego kredytu bankowego.

Wymagania banku dotyczące jakości gwarancji kredytowych poszczególnych grup przedsiębiorstw zdecydowanie się różnią. Generalnie są one zbieżne z postrzeganą przez bank wysokością ryzyka kredytowego określonej grupy przedsiębiorstw. Wzrost ryzyka niewypłacalności określonej grupy kredytobiorców prowadzi do generalnego podwyższenia wobec niej wymagań co do gwarancji [Bester, 1985].

Sztywna polityka banków w zakresie zabezpieczeń może prowadzić do poważnych ograniczeń $\mathrm{w}$ dostępie do kredytu dla nowo utworzonych przedsiębiorstw ze względu na wysokie ryzyko kredytowe (co implikuje wysokie wymagania związane z poziomem zabezpieczeń) oraz relatywnie małą wartość majątku własnego możliwego do wykorzystania jako zabezpieczenia bankowe. W wielu przypadkach konieczne jest poszukiwanie poręczeń spoza przedsiębiorstwa jako gwarancji spłaty kredytu (może to być np. prywatna nieruchomość przedsiębiorcy, jego prywatne aktywa itp.) [Ang, 1992].

B. Moore [1994] stwierdza, że firmy technologiczne mogą doświadczyć szczególnych trudności, gdyż ich wyposażenie techniczne jest przeważnie przygotowane do zastosowania w jednym specyficznym procesie produkcyjnym. Fakt ten wpływa na możliwość jego ewentualnej sprzedaży i w efekcie powoduje niewielką jego wartość jako zabezpieczenia ewentualnego kredytu. Dodatkowo znaczną część aktywów $\mathrm{w}$ firmach technologicznych stanowią wartości niematerialne, m.in. związane $\mathrm{z}$ wiedzą i umiejętnościami właściciela, które nie mogą być przez bank wykorzystane jako zabezpieczenie.

Trzecim z czynników, który należy uwzględnić przy analizie ograniczeń kredytowania nowo uruchomionych przedsiębiorstw technologicznych, jest problem rentowności akcji kredytowej. T. Łuczka [1997], powołując się na badania amerykańskie, wskazuje na prawidłowość, że wraz ze wzrostem rozmiarów kredytu bankowego zmniejszają się przeciętne koszty jednostkowe banku i na odwrót - wraz ze spadkiem jego rozmiarów przeciętne koszty jednostkowe rosną. Innymi słowy, oprocentowanie małego kredytu powinno być wyższe niż 
oprocentowanie dużego kredytu bankowego, ponieważ koszty opracowania małego kredytu $\mathrm{w}$ przeliczeniu na jednostkę kredytu są wyższe niż przeciętne koszty jednostkowe opracowania dużego kredytu bankowego. Istotnym czynnikiem, który może wpływać na kształtowanie się oprocentowania kredytu przez bank, jest zatem przeciętny jednostkowy koszt kredytu bankowego. Z punktu widzenia banku mały rozmiar kredytu jest w rezultacie istotnym czynnikiem kosztotwórczym i wywołuje podobne efekty ekonomiczne jak wielkość produkcji w przedsiębiorstwie przemysłowym: wraz ze wzrostem skali produkcji spada przeciętny koszt jednostkowy, stanowiący podstawę kształtowania ceny produktu ${ }^{13}$.

\section{Finansowanie firmy technologicznej zewnętrznym kapitałem wlasnym}

Z punktu widzenia tworzącego się przedsiębiorstwa jego kapitał własny jest stricte kapitałem ryzyka. Można go scharakteryzować jako sumę pieniędzy, jakie właściciele przedsiębiorstwa mogą stracić w przypadku niepowodzenia przedsięwzięcia [Binks, Vale, 1990]. Kapitał własny firmy może pochodzić:

1) $\mathrm{z}$ wpłat przedsiębiorcy(ów) - dotychczasowego(ych) właściciela(i) firmy - określany jest wtedy jako wewnętrzny kapitał własny,

2) z wpłat podmiotów z zewnątrz firmy - określany jest wtedy jako zewnętrzny kapitał własny.

Inwestowanie $\mathrm{w}$ kapitał własny firm, podobnie jak w przypadku kapitału obcego, łączy się $\mathrm{z}$ występowaniem problemu asymetrycznej informacji. Zagadnienie to jednak, ze względu na bardziej równomierne rozłożenie potencjalnego dochodu między inwestorem a emitentem kapitału własnego, kształtuje ten rynek w odmienny sposób. Można stwierdzić, iż inwestowanie w kapitał własny firm daje potencjalnemu inwestorowi możliwość sterowania podstawowymi czynnikami charakteryzującymi inwestycję: ryzykiem, dochodem i płynnością. Może to nastąić m.in. poprzez wybór rynku, na którym dokona się inwestycji. Inwestorzy o ograniczonej tolerancji ryzyka, zainteresowani umiarkowanym poziomem dochodu i dużą płynnością inwestycji, mają szansę zainwestować kapitał w papiery wartościowe dopuszczone do obrotu publicznego. Publiczny obrót papierami wartościowymi wymaga spełnienia wielu warunków określających tzw. dojrzałość spółki związaną z wysokością kapitału, jakim

\footnotetext{
13 Występowanie w warunkach polskich różnic polegających na zwiększaniu się oprocentowania kredytów wraz ze zmniejszaniem się rozmiaru firmy wykazane jest w: Łuczka, 1996: 4-11 oraz Polska Fundacja Promocji i Rozwoju Małych i Średnich Przedsiębiorstw, 1999: 208.
} 
dysponuje, osiaganego dochodu, ze stopniem dywersyfikacji produkcji i sprzedaży, wielkością obrotu, perspektywami rozwojowymi, wymaganą wielkością akcji skierowanych do obrotu publicznego i stopniem ich rozproszenia. Wymagania, które muszą spełnić przedsiębiorstwa ubiegające się o wejście ze swoimi akcjami na rynek publiczny, jak również dostępność informacji i wysoka płynność papierów wpływają na większe bezpieczeństwo inwestorów obecnych na tym rynku. Dla emitentów obrót publiczny zapewnia większą wiarygodność rynkową, weryfikację faktycznej wartości przedsiębiorstwa oraz łatwiejszy dostęp do kapitału. $\mathrm{Z}$ punktu widzenia firm zorganizowany rynek kapitałowy jest wydajnym i wygodnym mechanizmem pozyskiwania kapitału dla finansowania przedsiębiorstwa $\mathrm{w}$ bezpośrednim kontakcie $\mathrm{z}$ inwestorem prywatnym lub instytucjonalnym [Łuczka, 1997].

Rynek o uproszczonej procedurze dopuszczenia do obrotu tytułów własnościowych $^{14}$ jest zwykle rynkiem przeznaczonym dla inwestorów o relatywnie wysokiej tolerancji ryzyka i wyższej oczekiwanej stopie dochodu. Stwarza on jednocześnie możliwości pozyskania kapitału przez szerszą grupę przedsiębiorstw. Jest to rynek o niższych wymaganiach organizacyjnych, ekonomicznych i informacyjnych [Głodek, Pietras, 2011].

Charakterystyka inwestycji w powstające firmy technologiczne powoduje, że mają one szansę pozyskania kapitałów własnych jedynie poza zorganizowanym rynkiem kapitałowym. Ich finansowanie należy do zdecydowanie najbardziej ryzykownego segmentu rynku. Ryzyko powiązane jest zarówno $\mathrm{z}$ charakterystyką samego projektu, jak i faktem małej płynności inwestycji - długość okresu zwrotu zainwestowanego kapitału wynosi średnio od kilku do dziesięciu lat przy bardzo ograniczonych możliwościach wyjścia z inwestycji w czasie jej trwania.

Czynnikiem przyciągającym inwestorów do tego typu przedsiębiorstw jest potencjalny bardzo wysoki poziomu zwrotu $\mathrm{z}$ zainwestowanego kapitału. Powinien on być na poziomie znacznie przekraczającym dochody przewidywane $\mathrm{z}$ innych, bezpieczniejszych inwestycji na rynku (odpowiednim do poziomu ryzyka). Dochód ów będzie generowany głównie poprzez sprzedaż akcji (udziałów, praw majątkowych) firmy, w której dokonano inwestycji. Udział dywidendy czy zysków kapitałowych w całkowitym dochodzie inwestora jest zwykle minimalny (szczególnie w przypadku inwestycji we wczesnym etapie życia przedsiębiorstwa) $)^{15}$.

\footnotetext{
${ }^{14} \mathrm{~W}$ warunkach polskich takim rynkiem jest obecnie NewConnect.

15 Jednocześnie G. Murray [1996] stwierdza, że istnieje pewna liczba funduszy nastawionych na inwestycje w firmy rozwinięte, które - jak np. brytyjski 3i - konstruuja dochody całkowite na bazie rocznych dochodów kapitałowych. Taka sytuacja znacznie
} 
Dochody z inwestycji, oprócz wynagrodzenia za ryzyko ponoszone przez inwestora i za koszty utraconych korzyści, muszą również pokrywać koszty związane $\mathrm{z}$ oceną projektu oraz koszty związane $\mathrm{z}$ jego monitorowaniem [Binks, Vale, 1990]. Aby zabezpieczyć uzyskanie dochodu $\mathrm{z}$ inwestycji, inwestor zmuszony jest dokonać oceny i oszacowania stopnia realności danych zawartych w proponowanym przez przedsiębiorce projekcie inwestycyjnym oraz zapewnić zgodny z planem nadzór (monitoring) nad wykorzystaniem funduszy. Do oceny i monitorowania projektów niezbędna jest wiedza i doświadczenie związane $\mathrm{z}$ funkcjonowaniem na poszczególnych rynkach - większe zróżnicowanie sektorowe ocenianych propozycji inwestycyjnych wzmaga zapotrzebowanie na wiedzę. Inwestorzy, dążąc do obniżenia kosztów, często zawężają obszar zainteresowania inwestycyjnego do wybranych sektorów działalności gospodarczej oraz obszarów geograficznych.

Wzrost technicznego zaawansowania projektów również komplikuje sytuację inwestora. Do ich oceny niezbędna jest, droga do pozyskania, wysoce specjalistyczna wiedza. Co więcej, specjalizacja stosowanych rozwiązań technologicznych zwykle wyklucza ocenę dwóch projektów przez ten sam zespół ekspertów, wobec czego ich analiza jest czasoi kosztochłonna.

Cechą silnie wpływającą na rynek inwestycji w kapitał własny firm jest niewielka korelacja między kosztami oceny i monitoringu inwestycji a jej wielkością. Binks i Vale [1990] stwierdzają, że mogą one być w przybliżeniu uważane za koszty stałe (tzn. w podobnej wysokości). Sytuacja ta implikuje silny wpływ ekonomiki skali na podejmowane decyzje inwestycyjne. Wraz ze wzrostem skali inwestycji obniżają się koszty jednostkowe i zwiększa się efektywność inwestycji. W przypadku relatywnie małych projektów koszty jednostkowe rosną i pojawia się granica wielkości projektu, poniżej której inwestycje będą nieopłacalne ze względu na zbyt duże koszty obsługi projektu. Jednym z czynników, który mógłby wpłynąć na obniżenie minimalnego poziomu efektywności inwestycji jest wzrost zdolności do odpowiedniej oceny propozycji inwestycyjnych i co za tym idzie - zmniejszenie udziału niepowodzeń w portfelach inwestycyjnych i zwiększenie ogólnej zyskowności tego typu inwestycji.

Jednym z problemów inwestowania w małe firmy technologiczne jest zagadnienie wyceny wartości udziałów (akcji) w danym przedsięwzięciu,

redukuje potrzebę zbyt wczesnego lub odbywającego się w nieodpowiednim okresie wyjścia, lecz z drugiej strony dane przedsiębiorstwo musi mieć odpowiedni potencjał generowania gotówki. 
co jest konieczne do zawarcia umowy $\mathrm{z}$ przedsiębiorcą. Generalnie, w przypadku nowo utworzonego przedsiębiorstwa szacowanie kosztu kapitału za pomocą standardowych technik łączy się z poważnymi ograniczeniami związanymi m.in. [Brigham, 1996]:

1) w przypadku modelu stałego wzrostu $-\mathrm{z}$ faktem, że firma nie płaci i w dłuższym czasie nie będzie płacić dywidendy oraz z problematycznym oszacowaniem stopy wzrostu,

2) w przypadku metody związanej z dodaniem premii za ryzyko - z tym, że odnosi się ona tylko do firm, które emitowały obligacje, co w przypadku nowo utworzonych przedsiębiorstw jest nierealne,

3) z tym, że koncepcja Capital Asset Pricing Method (CAPM) jest bezużyteczna, jeśli dotyczy akcji firm, które nie są przedmiotem publicznego obrotu i w związku z tym nie można obliczyć współczynnika beta.

Obszarem szczególnych trudności finansowania kapitału własnego firm technologicznych są zagadnienia związane $\mathrm{z}$ szacowaniem wartości stanowiących bazę nowego przedsięwzięcia, składników niematerialnych (patentów, know-how) odnoszących się do nowej technologii. Wycena może być wykonana jedną z metod zaliczanych do dwóch zasadniczych grup, tj. grupy metod majątkowych lub grupy metod dochodowych [Stos, 1998]. Wycena metodami majątkowymi polega na określeniu wartości nakładów poniesionych na uzyskanie know-how we własnym zakresie lub na oszacowaniu wartości nabycia know-how w warunkach, gdy można mówić o istnieniu rynku określonych składników know-how. Wycena metodami dochodowymi polega na oszacowaniu dochodów, jakie przynosi występowanie know-how w strukturze przedsiębiorstwa. Do oszacowania tych dochodów można użyć metody dyskontowania strumieni pieniężnych. Główną trudność stanowi w tej metodzie właściwe oszacowanie dochodu ${ }^{16}$.

Pewne trudności mogą być również związane z wykorzystaniem knowhow jako aportu w przypadku założenia nowej firmy. Problem zdolności aportowej know-how budzi wiele kontrowersji, mimo że, jak stwierdza Stos [1998], trudno jest polemizować z tezą, że pozyskanie know-how wymaga nakładów i że nabywca know-how uzyskuje wymierne korzyści.

Trudności powoduje funkcja aportu jako czynnika pokrywającego zadeklarowany kapitał własny oraz funkcja kapitału podstawowego.

\footnotetext{
${ }^{16} \mathrm{~W}$ zależności od charakteru know-how jako dochód można rozumieć nie tylko bezwzględny zysk uzyskany dzięki zastosowaniu know-how, szacowany z uwzględnieniem wpływu know-how na strumień przychodów, ale także oszczędność na kosztach eksploatacyjnych (np. obniżenie kosztów zużycia materiałów) lub kapitałowych (np. obniżenie stanów zapasów).
} 
Uwzględniając te funkcje, należy przyjąć następujące kryteria zdolności aportowej dowolnego składnika majątkowego, a zatem i know-how:

1) powinien wykazywać zdolność do przeniesienia lub ustanowienia własności na rzecz podmiotu gospodarczego,

2) powinien mieć wymierną wartość bilansową jako składnik przedsiębiorstwa podmiotu gospodarującego,

3) powinien umożliwiać przeprowadzenie egzekucji.

Kryteria te wskazują, jak powinien wyglądać proces wnoszenia wkładu w tej postaci. Przede wszystkim fakt wniesienia know-how powinien być udokumentowany $\mathrm{w}$ sposób niebudzący wątpliwości, że nastąiło przeniesienie własności. Problemy mogą wystapić szczególnie w przypadku poufnego know-how, obejmującego np. tajemnice techniczne. Wnoszone poufne know-how powinno być dokładnie określone w poufnym dokumencie w celu umożliwienia jego identyfikacji.

\section{Referencje}

1. Abernathy W. J., Clark K. B., Innovation: Mapping the Winds of Creative Destruction, "Research Policy", vol. 14, 1985.

2. Aggarwal R., Technology, Globalization as Mutual Reinforces in Business: Reorienting Strategic Thinking for the New Millennium, "Management International Review", 2, 1999.

3. Ang J. S., On the Theory of Finance for Privately Held Firms, "Journal of Small Business Finance", 1(3), 1992.

4. van Auken H. E., Neeley L., The Impact of Planning on the Acquisition of Start-up Capital, raferat wygłoszony na International Council of Small Business Conference, 1998.

5. Behrens W., Hawranek P. M., Poradnik przygotowania przemystowych studiów feasibility, UNIDO, Warszawa, 1991.

6. Berry M. M. J., Taggart J. H., Combining technology and corporate strategy in small high tech firms, "Research Policy", 26, 1998.

7. Bester H., Screenings vs. Rationing in Credit Markets with Imperfect Information, "American Economic Review", vol. 75, 1985.

8. Binks M. R., The Relationship Between UK Banks and their Small Business Customers, [in:] Cressy R., Gandemo B., Olofsson C. (ed.), Financing SMEs - a comparatiwe perspective, Stockholm, NUTEK, 1996.

9. Binks M. R., Ennew C. T., Financing Small Firms, [in:] Burns P., Dewhurst J., Small Business and Entrepreneurship, Chippenham, MacMillan, 1996. 
10. Binks M., Vale Ph., Entrepreneurship and Economic Change, McGraw-Hill Book Company, London, 1990.

11. Brigham E. F., Podstawy zarzqdzania finansami, Państwowe Wydawnictwo Ekonomiczne, Warszawa, 1996.

12. Deakins D., Graham L., Logan D., Sullivan R., Understanding the Entrepreneurship Process in High Technology Small Firms, referat wygłoszony na $20^{\text {th }}$ ISBA National Small Firms and Research Conference, Belfast, 1997.

13. Douglas E., Shepherd D., New Venture Survival: Ignorance, External Shocks and Risk Reduction Strategies, Proceedings of the $43^{\text {rd }}$ ICSB World Conference, 1997.

14. Duhamel M., Franzetti P., Heese Ch., Research into the financing of new technology based firms, European Commission, 1995.

15. Gardner D. M., Johnson F., Lee M., Wilkinson I., A contingency approach to marketing high technology products, "European Journal of Marketing", vol. 34, no. 9/10, 2000.

16. Garnsey E., A New Theory of the Growth of the Firm, Proceedings of the $41^{\text {st }}$ ICSB World Conference, Stockholm, 1996.

17. Geroski P., Market Structure, Corporate Performance, and Innovative Activity, Clarendon Press, Oxford, 1994.

18. Głodek P., Łobacz K., The risk in strategic decisions of small innovative companies - model approach from the perspective of the entrepreneurial process, artykuł wygłoszony na $35^{\text {th }}$ DRUID Celebration Conference 2013, Barcelona, Spain, June 17-19, 2013.

19. Głodek P., Pietras P., Finansowanie komercjalizacji technologii i przedsięwzięć innowacyjnych opartych na wiedzy, Polska Agencja Rozwoju Przedsiębiorczości, Warszawa, 2011.

20. Hughes A., Moore B., High-Tech Firms: Market Position, Innovative Performance and Access to Finance, [in:] Cosh A., Hughes A. (ed.), Enterprise Britain, ESRC Centre for Business Research, Cambridge, 1998.

21. Jones-Evans D., Technical Entrepreneurship, Strategy and Experience, "International Small Business Journal", vol. 14, no 3, 1996.

22. Keasey K., Watson R., Investment and Financing Decisions and the Performance of Small Firms, National Westminster Bank, 1993.

23. Łobacz K., Koncepcja oceny procesu komercjalizacji przedsięwzięć gospodarczych $w$ akademickich inkubatorach przedsiębiorczości, rozprawa doktorska, Szczecin, 2012. 
24. Łuczka T., Kapitat jako przedmiot gospodarki finansowej matego $i$ średniego przedsiębiorstwa prywatnego, Wydawnictwo Politechniki Poznańskiej, Poznań, 1997.

25. Łukasik G., Polityka pozyskiwania kapitału przez przedsiębiorstwa $w$ warunkach rozwoju rynku finansowego, Wydawnictwo Uczelniane AE im. K. Adamieckiego w Katowicach, Katowice, 1998.

26. March J. G., Shapira Z., Managerial Perspectives on Risk and risk Taking, "Management Science", vol. 33, no 11, 1987.

27. Mason C. M., Harrison R. T., The Supply of Equity Finance in the UK: a Strategy for Closing the Equity Gap, "Entrepreneurship \& Regional Development", 1992.

28. Mazzarol T., Entrepreneurship and innovation. Readings and cases, second ed., Tilde University Press, 2011.

29. Moore B., Financial constrains to the growth and development of small high-technology firms, [in:] Hughes A., Storey D. J. (ed.), Finance and the Small Firm, Routledge, London, 1994.

30. Moore I., Garnsey E., Funding for innovation in small firms: the role of government, "Research Policy", 1992.

31. Oakey R. P., High Technology New Firms: Variable Barriers to Growth, PCP, London, 1995.

32. Oakey R., Mukhtar S. M., United Kingdom High Technology Small Firm in Theory and Practice: a Review of Recent Trends, referat wygłoszony na SME Conference, Mikkeli, Finland, 1998.

33. Polska Fundacja Promocji i Rozwoju Małych i Średnich Przedsiębiorstw (PFPiRMiŚP), Raport o stanie sektora matych $i$ średnich przedsiębiorstw w Polsce w latach 1997-1998, Warszawa, 1999.

34. Porter M., Strategia konkurencji, PWE, Warszawa, 1996.

35. Roberts E. B., Entrepreneurs in High-technology, Oxford University Press, Oxford, 1991.

36. Shane S., A general theory of entrepreneurship. The individualopportunity nexus, Edward Elgar Publishing, Cheltenham, UK, Northampton USA, 2004.

37. Smallbone D., Leigh R., North D., The characteristics and strategies of high growth SMEs, "International Journal of Entrepreneurial Behaviour \& Research", 1(3), 1995.

38. Spann M. S., Adams M., Seed Funding form High Technology Ventures: the Role of the Bridge Business, referat wygłoszony na ICSB Conference, 1997. 
39. Stankiewicz R., Spin-off companies from universities, "Science and Public Policy", vol. 21, no. 2, 1994.

40. Stiglitz J., Weiss A., Credit Rationing In Markets With Imperfect Information, "American Economic Review", vol. 71, 1981.

41. Storey D. J., Understanding the small business sector, Routledge, London, 1994.

42. Storey D. J., Tether B. S., New technology-based firms in the Europe, European Commission, Directorate General XIII, 1996.

43. Stos D., Wybrane aspekty 'know-how' jako czynnika wartości niematerialnych $i$ prawnych $w$ strukturze majatku podmiotu gospodarczego, referat wygłoszony na sympozjum „Finansowanie małych firm innowacyjnych”, Centrum Transferu Technologii, Łódź, czerwiec, 1998.

44. Williamson O. E., Markets and Hierarchies. Analysis and Antitrust Implications. The Free Press, New York, 1975.

\begin{abstract}
The chapter examines the problems of new company creation and how various different factors as risk and capital access relate to start-ups management. We use basically theoretical description based on world literature but the practical examples are often indicated. The major issues are summarized as follows. First, risk and its influence on start-up creation is being analyzed based on novelty and capital firm's needs. Second, it is found that, consequences of the value of new start-up external financial need is also the future investment loses. Additionally, the new firms perspectives are affected by new knowledge and new technologies used in company development and the characteristics profiles of technology company owners.
\end{abstract}

